\title{
Müller Glial Cells in Retinal Disease
}

\author{
Andreas Bringmann Peter Wiedemann \\ Department of Ophthalmology and Eye Hospital, University of Leipzig, Leipzig, Germany
}

\section{Key Words}

Müller cell · Gliosis · Glutamate toxicity · Antioxidants ·

Adenosine $\cdot$ Edema

\begin{abstract}
Virtually all pathogenic stimuli activate Müller cells. Reactive Müller cells exert protective and toxic effects on photoreceptors and neurons. They contribute to oxidative stress and glutamate toxicity due to malfunctions of glutamate uptake and glutathione synthesis. Downregulation of potassium conductance disrupts transcellular potassium and water transport, resulting in neuronal hyperexcitability and edema. Protective effects of reactive Müller cells include upregulation of adenosine $5^{\prime}$-triphosphate (ATP)-degrading ectoenzymes, which enhances the extracellular availability of the neuroprotectant adenosine, abrogation of the osmotic release of ATP, which might protect retinal ganglion cells from apoptosis, and the release of antioxidants and neurotrophic factors. The dedifferentiation of reactive Müller cells to progenitor-like cells might have an impact on future therapeutic approaches. A better understanding of the gliotic mechanisms will be helpful in developing efficient therapeutic strategies aiming at increased protective and regenerative properties and decreased toxicity of reactive Müller cells.
\end{abstract}

Copyright $\odot 2011$ S. Karger AG, Basel
(C) 2011 S. Karger AG, Basel

$0030-3755 / 12 / 2271-0001 \$ 38.00 / 0$

Fax +41613061234

E-Mail karger@karger.ch

www.karger.com
Accessible online at:

www.karger.com/oph

\section{Introduction}

In addition to microglial cells, the resident immune cells of the retina, the retina contains two types of macroglial cells: astrocytes and Müller cells [1]. Astrocytes play a crucial role in retinal vascularization $[2,3]$; in the mature retina, they are restricted to the nerve fiber and ganglion cell layers $[4,5]$.

The human retina contains 8-10 million Müller cells. Each Müller cell constitutes the core of a column of retinal neurons, which represents the smallest functional unit for 'forward information processing' [6]. Müller cells interact with the neurons of their columns in a kind of symbiotic relationship and are responsible for the functional and metabolic support of their associated neurons $[1,7]$. Müller cells provide neurons with trophic substances and remove metabolic waste. They play a critical role in regulating the extracellular space volume, ion and water homeostasis, and in maintaining the inner blood-retinal barrier. They release gliotransmitters and other neuroactive substances, and have an impact on synaptic activity by neurotransmitter recycling, which involves the supply of neurons with precursors of neurotransmitters [8]. All these functions directly or indirectly modify neuronal activity. Müller cells support the survival of photoreceptors and neurons, are responsible for the structural stabilization of the retina, and modulate immune and inflammatory responses $[7,8]$. They guide the light to the

Peter Wiedemann, MD

Department of Ophthalmology and Eye Hospital

Faculty of Medicine, University of Leipzig

Liebigstrasse 10-14, DE-04103 Leipzig (Germany)

Tel. +49 341972 1651, E-Mail Peter.Wiedemann@medizin.uni-leipzig.de 
photoreceptors [9] and buffer mechanical deformations of the retinal tissue [10]. Müller cells become activated by virtually all pathogenic stimuli $[7,11]$. Reactive Müller cells are neuroprotective but may also stop supporting the neurons and, instead, contribute to neuronal degeneration. This article provides a short overview of the involvement of Müller cells in pathological processes of the retina. Currently, the numerous roles of Müller cells in retinal disease are not fully understood, and are the subject of ongoing research. Much of the current knowledge about Müller cell functions and dysfunctions was derived from animal models and cultured Müller cells, and thus awaits confirmation in human cells in situ.

\section{Müller Cell Gliosis}

Reactive gliosis is thought to represent a cellular attempt to protect retinal tissue from further damage, to promote retinal tissue repair, and to limit tissue remodeling $[7,8]$. It includes morphological, biochemical, and physiological changes; these responses vary with the type and severity of the insult. Upregulation of the glial intermediate filaments vimentin and glial fibrillary acidic protein (GFAP) (fig. 1b) is a very sensitive early indicator of 'retinal stress' $[7,12,13]$. Other gliotic alterations in- clude Müller cell hypertrophy and proliferation, and dedifferentiation to progenitor-like cells (see below) [8].

Müller cell gliosis has both protective and toxic effects on retinal neurons $[7,8]$. Particularly under conditions of massive (proliferative) gliosis, the regular glial-neuronal interactions are disrupted and the retina degenerates. An inverse relation between Müller cell proliferation and the expression of neuron-glia symbiosis-mediating proteins has been observed [14-21]. However, dysfunction of Müller cells may also contribute to neurodegeneration in the case of 'conservative' gliosis (associated with short-term or low-level Müller cell proliferation). After retinal detachment, for example, downregulation of cellular retinaldehyde-binding protein (usually involved in cone photopigment recycling [22]) and glutamine synthetase $[14,15]$ disrupts the glial-neuronal interactions involved in photopigment and neurotransmitter recycling. Downregulation of carbonic anhydrase $[14,15]$ and inwardly rectifying potassium (Kir) channels (fig. 1d, 2, 3a, b, d) [23-38] results in disturbances of retinal acid-base, ion and water homeostasis (see below) $[7,39]$.

The involvement of reactive Müller cells in immune and inflammatory responses may also exert detrimental effects. After retinal injury, such as retinal detachment, Müller cells upregulate inflammatory factors, including monocyte chemoattractant protein-1, which recruit
Fig. 1. Müller cell reactivity in a blue light-injured rat neuroretina. a Focal illumination of the rat retina with excessive blue light results in apoptotic degeneration of photoreceptor cells as indicated by the disappearance of aquaporin-1 immunoreactivity in the photoreceptor segment (PRS) layer and outer nuclear layer (ONL; right). Slices of a control retina (left) and a retina obtained 3 days after light treatment (right) were immunostained against aquaporin-1 (red) and the Müller cell marker glutamine synthetase (blue). Blood vessels and activated immune cells were labeled with isolectin (green). Usually, aquaporin-1 is localized to photoreceptor cells, a class of glycinergic amacrine cells (white arrow), and erythrocytes within the vessels (white arrowheads). Yellow arrowhead: isolectin-stained invading macrophage. b Localization of GFAP (green) and aquaporin-4 (red) immunoreactivities in slices of a control retina and a retina 2 days after light treatment. Note that both immunoreactivities are largely absent from the ONL under control conditions, and present after light treatment. Also note the diappearance of aquaporin- 4 immunoreactivity in the outer plexiform layer (OPL), indicating early loss of ribbon synapses after light treatment. Blue stain: cell nuclei. c Blue-light injury is associated with disruption of the outer blood-retinal barrier, resulting in extravasation of blood proteins such as IgG and invasion of macrophages into the outer nuclear layer, which phagocytize the debris of degenerated photoreceptors. Slices of a control retina (left) and a retina 3 days after blue-light treatment were stained against IgG (green) and with isolectin (blue) which labels blood vessels and activated immune cells including macrophages (arrows). The presence of IgG-labeled Müller cell fibers (arrowhead) indicates that Müller cells phagocytize blood-derived proteins. The left sides show differential interference contrast (DIC) images of the slices. d Potassium currents of 2 Müller cells isolated from a control retina and a retina 3 days after light treatment (left). Note the decreased Kir currents after light treatment. The bar diagram on the right displays the time-dependent decrease in the mean Kir currents of Müller cells after blue-light treatment of the retina. e Blue-light injury alters the osmotic swelling properties of Müller cells. The cross-sectional area of Müller cell somata was measured in slices of untreated (control) retinas and of retinas isolated 3 days after light exposure. Acute exposure of the slices to a hypoosmolar solution (60\% of normal osmolarity) induced time-dependent swelling of Müller cell bodies in light-injured retinas, and had no effect on the size of Müller cell bodies in control retinas. The insets display original records of a dye-filled Müller cell soma in a slice of a light-injured retina, obtained before (left) and during (right) hypoosmotic exposure. Scale bar: $5 \mu \mathrm{m}$. GCL = Ganglion cell layer; INL $=$ inner nuclear layer; IPL $=$ inner plexiform layer. Scale bars, $20 \mu \mathrm{m}$ and $5 \mu \mathrm{m}$ (insets). 


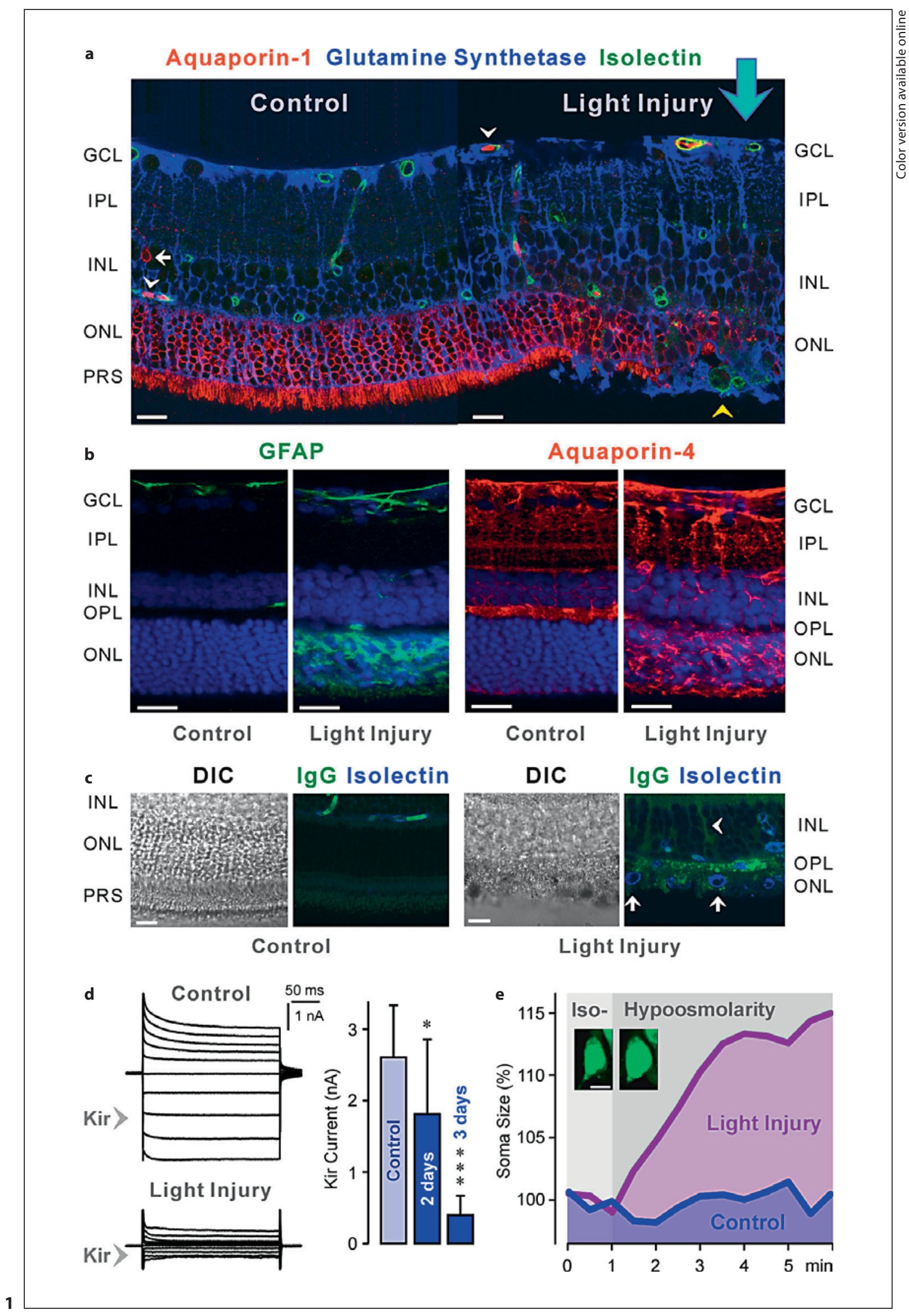


phagocytotic monocytes/macrophages and microglial cells to the injured area $[40,41]$. Invading macrophages and neutrophils release oxygen free radicals and cytotoxic cytokines, which play critical roles in photoreceptor apoptosis after retinal detachment [42] and in neuronal degeneration after ischemia-reperfusion [43]. Vimentinand GFAP-deficient mice display an attenuation of distinct detachment-induced glial responses [activation of extracellular signal-regulated kinases (ERK1/2) and cFos, induction of monocyte chemoattractant protein-1] and, as a consequence, decreased monocyte infiltration and photoreceptor apoptosis [44]. A similar recruitment of blood-derived macrophages into the retinal tissue was observed after experimental blue-light retinal injury (fig. 1a, c) [34].

On the other hand, reactive Müller cells might also protect photoreceptors and neurons from cell death by various mechanisms, including the secretion of neurotrophic and growth factors, in particular basic fibroblast growth factor (bFGF, FGF-2) [45-47]. The glial cell line-derived neurotrophic factor (GDNF) induces phosphorylation of ERK1/2 in Müller cells, resulting in transcriptional upregulation of bFGF that in turn supports photoreceptor survival $[47,48]$. GDNF also protects photoreceptors and ganglion cells from apoptosis through upregulation of the glial glutamate-aspartate transporter (GLAST) $[49,50]$. Retinal preconditioning with bright light or mechanical stress protects photoreceptors from apoptosis because these stimuli induce upregulation of bFGF and ciliary neurotrophic factor in Müller cells [45, 51]. Likewise, argon laser photocoagulation slows photoreceptor degeneration by induction of bFGF in Müller cells [52]. Other neuroprotective effects of gliosis include the production and release of antioxidants, such as glutathione (see below), pyruvate, $\alpha$-ketoglutarate, metallothionein, lysozyme, ceruloplasmin, heme oxygenase and reduced ascorbate [41, 53-58]. Müller cells phagocytize cellular debris [59] and bloodderived proteins (fig. 1c).

\section{Glial Scars}

Retinal gliosis might result in the formation of glial scars, which inhibit retinal remodeling and regular regeneration of the injured retinal tissue [8]. Usually, Müller cells are softer than neurons [10]. As growing neurites prefer soft substrates [60], soft glial processes may support the growth of neuronal processes implicated in synaptic plasticity [10]. However, gliotic Müller cells display increased stiffness due to upregulation of intermediate filaments, in particular of GFAP (fig. 1b); this will inhibit neurite growth and might be one reason for aberrant retinal tissue repair after retinal injury [61]. The increased stiffness of gliotic Müller cells might also be responsible for the fact that, in retinal neovascularization, new blood vessels grow towards the vitreous rather than within retinal tissue [62]. In addition, gliotic Müller cells increase the expression of extracellular matrix and cell adhesion molecules [63-70]; these molecules function as chemical inhibitors of axonal growth and neuronal regeneration [71-74]. However, glial inhibition of retinal tissue remodeling is incomplete [75]. Aberrant neurite sprouting and neuronal migration to ectopic sites along the surface of hypertrophied Müller cells were observed in age-related macular degeneration, retinal detachment and proliferative vitreoretinopathy [76-81]. The formation of glial scars may also be a reason for the failure of visual recovery after subretinal implantation of microphotodiode arrays [82]. Scar tissue may function as an electrical barrier between the implant and retinal neurons.

\section{Epiretinal Membrane Formation}

Epiretinal membranes are a distinct type of scars that are connected to the retinal tissue by hypertrophied Müller cell fibers $[70,76,83]$. These membranes were suggested to protect retinal tissue from the effects of pathogenic factors present in the vitreous [84]. After partial detachment of the vitreous from the retina, vitreous fibers adhering to Müller cells at sites of vitreoretinal attachment exert tractional forces onto the cells; this activates the cells and results in cellular hypertrophy and proliferation as well as vascular leakage [85]. Mechanical stress induces calcium responses (likely induced by stretch-activated calcium-permeable cation channels [86]), activation of ERK1/2, and upregulation of the transcription factor c-Fos and of bFGF in Müller cells [87]. Mechanically stressed Müller cells release growth factors (e.g. bFGF) and adenosine 5'-triphosphate (ATP) [87-89]. Calcium influx [through stretch-activated and voltagegated calcium channels, and ionotropic purinergic $\left(\mathrm{P}_{2} \mathrm{X}_{7}\right)$ receptor channels] and subsequent activation of calciumactivated big-conductance potassium (BK) channels are required for growth factor- and ATP-induced proliferation of Müller cells [90-94]. 


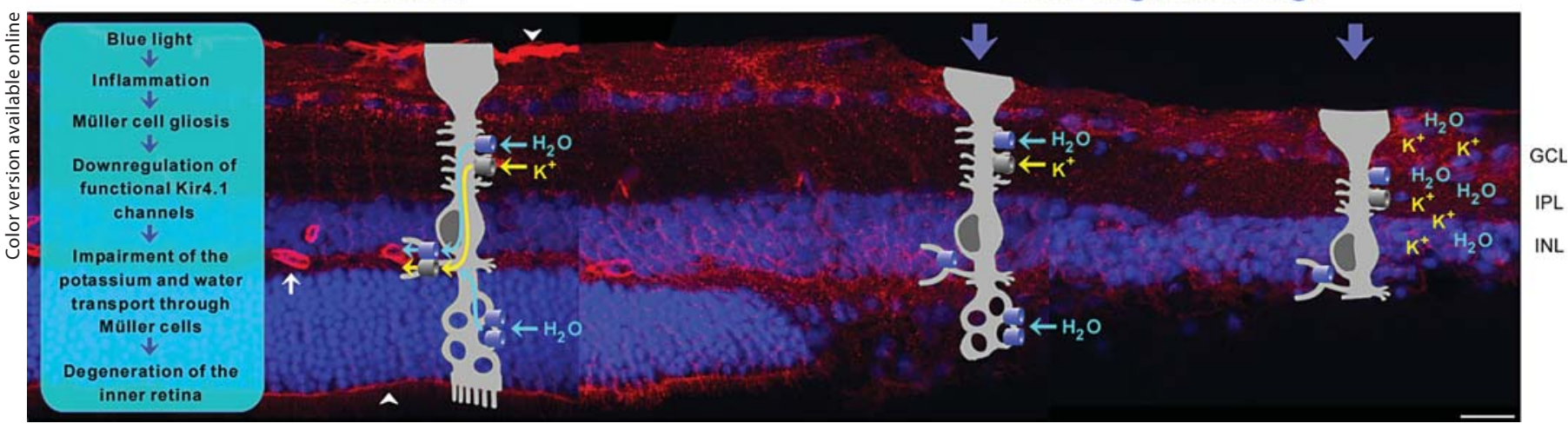

Fig. 2. Putative involvement of Müller cell dysfunction in the degeneration of the inner retina after exposure to blue light. Excess illumination with blue light causes degeneration of the photoreceptors and the pigment epithelium, resulting in local inflammation which induces Müller cell gliosis. Gliosis is associated with redistribution of the Kir4.1 protein (red) from the prominent expression sites around the vessels (white arrow) and at the limiting membranes of the retina (white arrowheads). Redistribution and functional inactivation of Kir4.1 disrupt the transglial potassium and water flux (middle), resulting in dysfunctional potassium and water homeostasis within the retinal tissue. This contributes to edema development and neuronal degeneration in the inner retina as indicated by the decrease in the thickness of the inner retina, especially of the inner plexiform layer (IPL; right). Cell nuclei are stained blue. $\mathrm{GCL}=$ Ganglion cell layer; $\mathrm{INL}=$ inner nuclear layer. Scale bar: $20 \mu \mathrm{m}$.

\section{Malfunction of Glutamate Uptake}

Glutamate toxicity is a major cause of neuronal loss in many retinal disorders, including glaucoma, ischemia, diabetes, and inherited photoreceptor degeneration [95102]. Malfunction and/or downregulation of glial glutamate transporters contribute to the rise in extracellular glutamate towards excitotoxic levels [103-105]. Usually, Müller cells remove the bulk of extracellular glutamate from inner retinal tissue [106-112]. In the outer plexiform layer, Müller cells prevent the lateral spread of glutamate beyond the synapses, thus ensuring visual resolution [8].

GLAST is the major glutamate uptake carrier of Müller cells [108, 113-118]. As the amplitude of glutamate transport is voltage dependent (fig. 4a), a very negative membrane potential is essential for an efficient glutamate uptake [119-123].

In retinal ischemia and diabetes, the efficiency of glutamate transport into Müller cells is reduced [104, 124]. In experimental glaucoma, reduced GLAST activity coincides with excitotoxic damage to the retina [105]. The decreased glial glutamate uptake is mainly caused by cellular depolarization. Depolarization of Müller cells occurs as a result of pathological rises in extracellular potassium (as observed in ischemia and glaucoma), malfunction of the $\mathrm{Na}^{+}, \mathrm{K}^{+}$-ATPase induced, for example, by inflammatory lipids such as arachidonic acid and prostaglandins, opening of cation channels in the Müller cell membrane (fig. 4b), and a decrease in the potassium permeability of Müller cell membranes after inactivation and/or downregulation of Kir channels [1, 20, 23, 125-130]. Inactivation of Kir channels was observed in animal models of various retinopathies and in Müller cells from patients with proliferative retinopathies (fig. 1d, 3a, b, d, 5a) (see below).

Depolarization of Müller cells may even cause a reversal of glutamate transport [131-133]. Glutamate and aspartate released through glial glutamate transporters are implicated in excitotoxic damage to retinal ganglion cells $[133,134]$. Release of glutamate from Müller cells might also be mediated by the cystine-glutamate antiporter (which is activated when increased production of the antioxidant glutathione requires increased uptake of cystine; see below) and by exocytosis of glutamate-containing secretory vesicles [135-138].

Hypoxia increases mitochondrial peroxide production; the resulting lipid peroxidation disrupts glutamate transport into Müller cells [139]. This mechanism is probably implicated in the neuronal dysfunction in diabetic retinopathy [124] and ganglion cell death in Leber hereditary optic neuropathy [140]. Inflammatory lipids, such as arachidonic acid, and a reduction in extracellular $\mathrm{pH}$ as it occurs in ischemia also directly inhibit glial glutamate uptake $[132,141]$. 
Various diseases are associated with a breakdown of the blood-retinal barrier, resulting in extravasation of blood constituents (fig. 1c). Blood plasma and other blood constituents, like thrombin, inhibit the Kir channels and induce Müller cell depolarization [142, 143]. The reduced efficiency of glial glutamate transport may partly explain the clinical observation that the presence of hemorrhages at sites of vascular leakage is associated with a greater reduction in retinal function [144].

\section{Malfunction of Glutathione Synthesis}

The retina has a high need for antioxidant protection; this results from light exposure together with the high oxygen consumption of photoreceptors, the weak autoregulation of choroidal blood flow in response to the oxygen requirements of photoreceptors $[145,146]$, and the high levels of polyunsaturated fatty acids in photoreceptors. In addition, the outer retina underlies circadian periods of hypoxia (dark) and hyperoxia (light) $[147,148]$; both increase the oxidative stress in the retinal tissue. Müller cells produce the antioxidant glutathione, a tripeptide synthesized from glutamate, cysteine and glycine [149-152]. In response to hypoxia, hypoglycemia and oxidative stress, glutathione is rapidly released from Müller cells and made available to the neurons $[58,151,153]$. The glial release of antioxidants like glutathione and of neuroprotective factors like bFGF and adenosine participates in the protection of photoreceptors from the harmful effects of circadian light exposure [154-156].

Glutathione synthesis is dependent on the availability of extracellular glutamate and cystine [150, 157]. The decreased glutamate uptake by Müller cells in diabetic retinopathy reduces glutathione synthesis $[150,158]$ and results in upregulation of glutaredoxin which induces nuclear translocation of NF- $\mathrm{\kappa B}$ and expression of proinflammatory factors [159]. Müller cells from aged animals contain reduced levels of glutathione; this is associated with mitochondrial damage, membrane depolarization and reduced cell viability $[160,161]$. The age-dependent decrease in retinal glutathione may accelerate the pathogenesis of retinopathies in the elderly. Externally administered radical scavengers like Ginkgo biloba extract enhance the intrinsic glutathione content of aged Müller cells and protect the mitochondria from the damaging action of free radicals $[160,161]$.

\section{Extracellular Formation of Adenosine}

Adenosine is a major neuroprotectant involved in the retinal response to ischemia-hypoxia and hypoxic states of photoreceptors in the dark [156, 162-166]. Adenosine has anti-inflammatory effects, induces retinal hyperemia
Fig. 3. In the course of retinal ischemia-reperfusion, rat Müller cells alter their membrane conductance, osmotic swelling properties and Kir channel expression. Transient retinal ischemia was induced by elevation of the intraocular pressure above the systolic blood pressure for $1 \mathrm{~h}$. a Examples of the whole-cell potassium currents of Müller cells isolated from a control retina, and from retinas 3 and 7 days after transient retinal ischemia. b The amplitude of the Kir currents decreases time dependently after transient retinal ischemia. Simultaneously, the resting membrane potential (RMP) of the cells decreases and the whole-cell capacitance (that is proportional to the cell membrane area) increases, indicating cellular hypertrophy. The parameters were measured at different periods ( $3 \mathrm{~h}$ to 3 days) after transient ischemia. c Under hypoosmotic stress, Müller cells in slices of retinas 3 days after ischemia display cellular swelling, which is not observed in Müller cells in slices of control retinas. The time-dependent alteration in the cross-sectional area of Müller cell somata is shown. The images display Müller cell somata in a postischemic retina, before (above) and after (below) hypotonic challenge. Scale bar: $5 \mu \mathrm{m}$. d Immunolocalization of glial Kir channel proteins in normal and postischemic rat retina. The Kir4.1 protein is predominantly localized at the limiting membranes of the retina (arrow- heads) and around the blood vessels (arrows). Kir2.1 protein is localized in the inner retina in membrane domains of Müller cells that abut on neuron compartments, e.g. processes that cross the inner plexiform layer (IPL) (arrowheads). Seven days after transient retinal ischemia, Kir4.1 protein expression is largely downregulated, whereas the localization of Kir2.1 protein is unaltered. Note the decrease in the thickness of the inner retina, which is a characteristic of retinal ischemia-reperfusion injury. Scale bars: $20 \mu \mathrm{m}$. e Scheme of the potassium-buffering currents flowing through Müller cells during neuronal activation. Activated neurons release potassium which is absorbed by Müller cells through Kir2.1 and Kir5.1/4.1 channels, and distributed into the blood vessels, the vitreous and the subretinal space through Kir4.1 channels. Kir4.1 channels mediate in- and outward currents and thus contribute to the osmohomeostasis between the neuroretina and extraretinal fluid-filled spaces. The diagrams display the currentvoltage (I-V) relations of Kir4.1 and Kir2.1 channels. Kir4.1 channels mediate inward and outward potassium currents with similar amplitudes, whereas Kir2.1 channels mediate inward currents and almost no outward currents. GCL = Ganglion cell layer; $\mathrm{INL}=$ inner nuclear layer; $\mathrm{IPL}=$ inner plexiform layer; $\mathrm{ONL}=$ outer nuclear layer. 

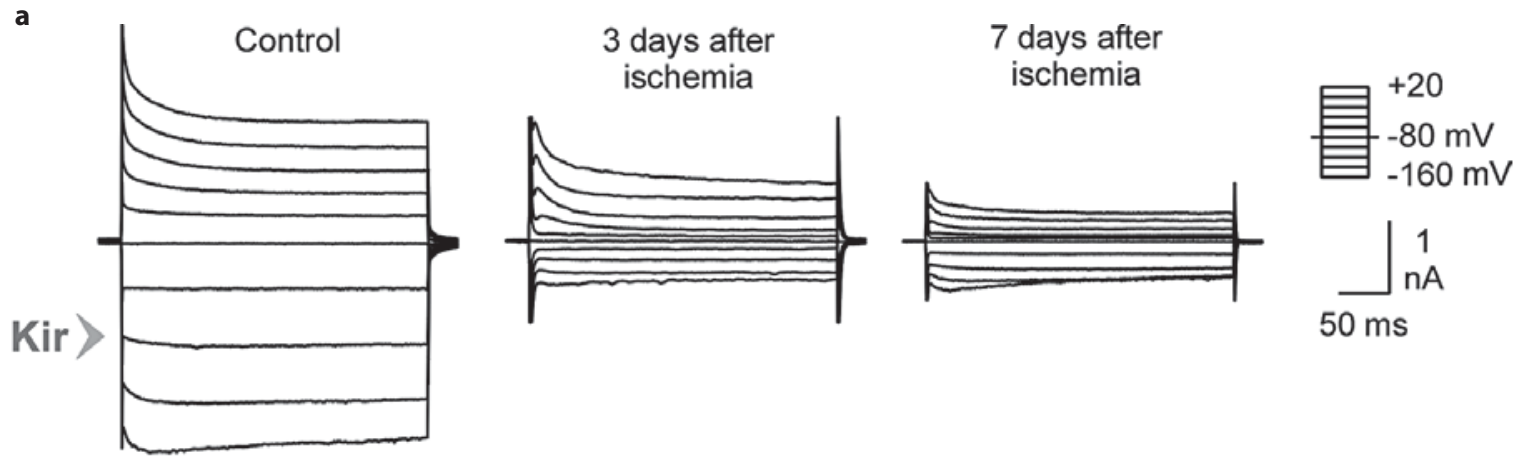

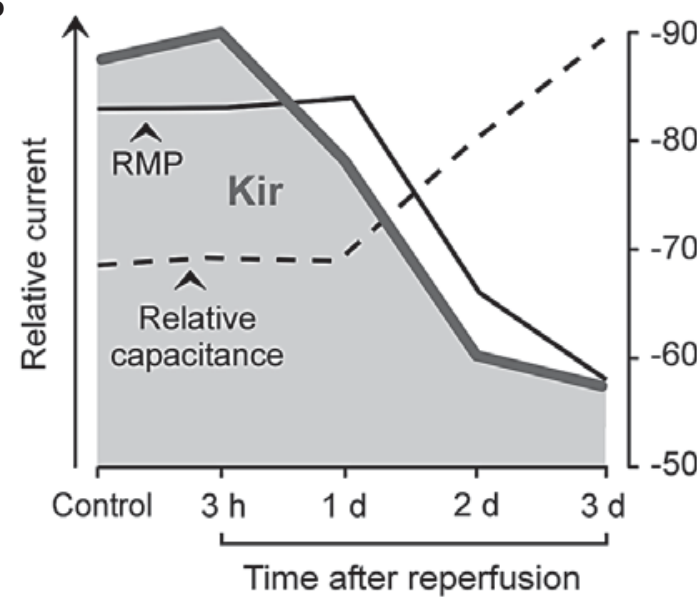

d

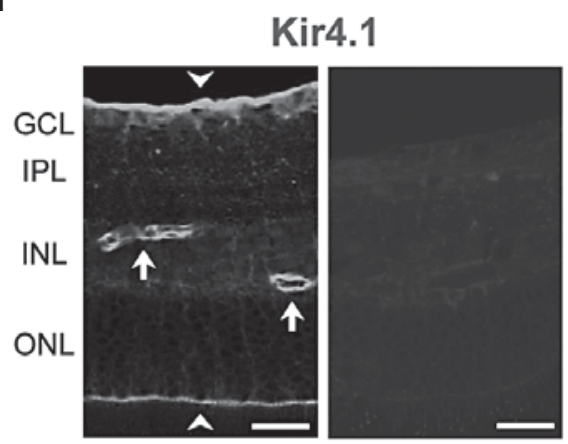

Kir2.1

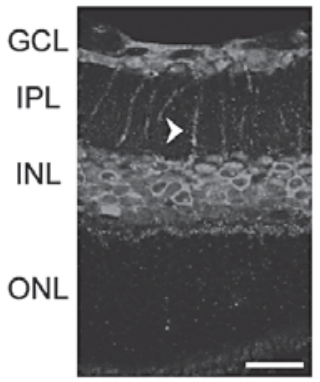

Control

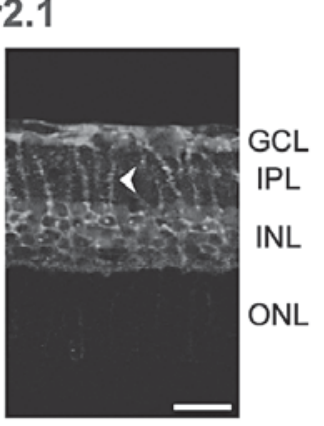

Ischemia

\section{LL}

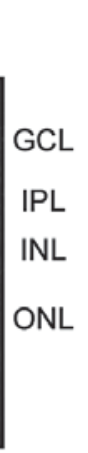
(a)

e

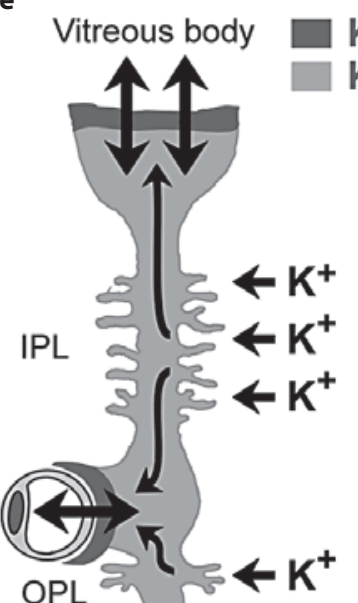

Kir4.1

Kir2.1 + Kir4.1/5.1

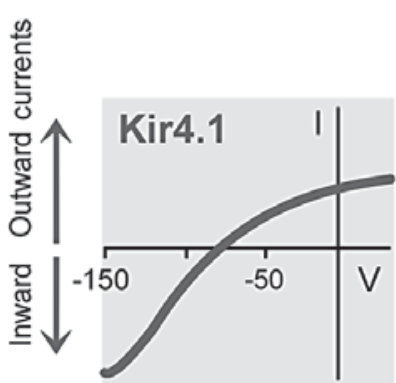

Subretinal space

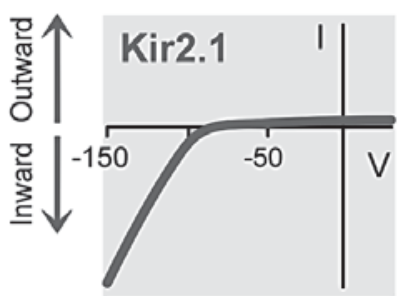


after ischemia and protects neurons from glutamate toxicity by suppressing excitatory neurotransmission [162, $164,166,167]$. Adenosine also inhibits osmotic swelling of Müller cells (see below); this prevents detrimental reductions in extracellular space volume which otherwise would result in neuronal hyperexcitation $[168,169]$.

Usually, Müller cells release adenosine through nucleoside transporters; this release is implicated in Müller cell volume regulation (fig. 6b) [35, 138, 170-174]. Adenosine cannot be extracellularly generated from ATP because the retinal parenchyma lacks the nucleoside triphosphate diphosphohydrolase (NTPDase) 1 (fig. 6a) [175-177]. NTPDasel catalyzes the degradation of ATP and adenosine 5'-diphosphate (ADP) to adenosine 5'monophosphate (AMP) [178]. AMP is the substrate of the ecto-5'-nucleotidase (fig. 6a) which catalyzes the hydrolyzation of AMP to adenosine. NTPDase1 is exclusively localized to the retinal vasculature, while the retinal parenchyma contains NTPDase2 (fig. 6a) [175-177]. NTPDase2 preferentially catalyzes the degradation of ATP to ADP [179].

In experimental diabetic retinopathy, Müller cells upregulate NTPDasel expression (fig. 6a) [171]. This enables extracellular adenosine formation by the consecutive action of NTPDasel and ecto-5'-nucleotidase (fig. 6b). NTPDasel upregulation increases the availability of extracellular adenosine and results in a more effective clearance of ATP from the extracellular space. In experimental glaucoma, extracellular ATP (acting at $\mathrm{P}_{2} \mathrm{X}_{7}$ receptors) mediates the apoptotic death of retinal ganglion cells [180, 181]. Retinal glial cells are a major source of extracellular ATP $[88,89]$. As Müller cells release ATP in response to mechanical stimuli $[88,89]$, ATP is increasingly liberated from Müller cells in the presence of mechanical perturbations like retinal detachment and elevated intraocular pressure [181-183]. As adenosine inhibits the ATP-induced retinal ganglion cell apoptosis, the balance between extracellular ATP and adenosine levels determines the level of ganglion cell death [184]. The upregulation of NTPDasel in the diseased retinal parenchyma (fig. 6a) [171] may decrease the extracellular ATP levels and, thus, prevent retinal ganglion cell death.

\section{Dysfunctional Retinal Potassium Homeostasis}

Light onset causes increases in extracellular potassium in the plexiform layers $[185,186]$. If not corrected, increased potassium will cause neuronal hyperexcitation.
Müller cells buffer imbalances in the extracellular potassium concentration via permission of transcellular potassium currents [187-189]. They take up excess potassium from the extracellular space, and release equal amounts of potassium into fluid-filled spaces outside the neuroretina (blood vessels, vitreous and subretinal space; fig. 3e) [187-189].

Because Müller cell membranes are highly permeable to potassium [190, 191], Müller cells usually have a very negative resting membrane potential, around $-80 \mathrm{mV}$ [190, 192, 193]. Potassium permeability is mainly mediated by potassium channels belonging to the Kir subfamily [194]. In particular, Kir4.1 (which mediates bidirectional potassium currents; fig. 3e) and Kir2.1 channels (which mediate inward potassium currents) are implicated in potassium buffering $[195,196]$. The channel proteins are localized in a polarized fashion in the Müller cell membrane. Homomeric Kir4.1 channels are mainly localized in membrane domains across which the cells extrude potassium into spaces outside the neuroretina (perivascular membranes and at both limiting membranes of the retina; fig. 2, 3d) [195, 197]. Membranes which abut neuronal cell structures contain Kir channels that mediate inward potassium currents, i.e. Kir2.1 (fig. 3d) and heterotetrameric Kir4.1/Kir5.1 channels [32, 196, 198].

Many of the homeostatic functions of Müller cells, including potassium buffering and neurotransmitter uptake, depend on the very negative membrane potential constituted by Kir4.1 channels [195]. Kir4.1 channels of Müller cells are dislocated and/or downregulated under various pathological conditions (fig. $2,3 \mathrm{~d}, 5$ ); this results in a decrease in the potassium currents across Müller cell membranes (fig. 1d, 3a, b). Such alterations have been observed in animal models of various retinal diseases, including ischemia-reperfusion, inflammation, diabetic retinopathy, blue-light injury, detachment, vein occlusion and proliferative vitreoretinopathy, as well as in Müller cells from patients with proliferative retinopathies (fig. 5a) [17-20, 23-38, 199]. Ischemia causes a decrease in Kir4.1 (but not Kir2.1) expression (fig. 3d) [32]. Inactivation of Kir4.1 impairs potassium transport through Müller cells and causes cell depolarization which impairs the glutamate uptake (see above). Human Müller cells display an age-dependent decrease in Kir currents (fig. 5b) [200]. This decrease enhances susceptibility to age-dependent retinopathies when additional pathological complications like diabetic alterations of the blood vessels are present. 
Fig. 4. The glutamate transport into Müller cells is voltage dependent. a Administration of glutamate $(1 \mathrm{mM})$ to a rabbit Müller cell generates an inward current at negative membrane potentials (left). The current-voltage relation of the glutamate transporter currents in guinea pig Müller cells (right) shows that the efficiency of glutamate transport increases with increasing (i.e. more negative) membrane potentials. $\mathbf{b}$ Activation of the cation conductance of purinergic $\mathrm{P} 2 \mathrm{X}_{7}$ receptors in human Müller cells by 2'-/3'-O-(4-benzoylbenzoyl)-ATP (BzATP) impairs glutamate uptake by Müller cells. The uptake currents evoked by glutamate (Glu; $100 \mu \mathrm{M}$; arrows) are abrogated in the presence of BzATP (10 $\mu \mathrm{M})$. Inhibition of $\mathrm{P}_{2} \mathrm{X}_{7}$ receptor activation by $\mathrm{KN}-62(1 \mu \mathrm{M})$ suppressed the BzATP-evoked current, resulting in glutamate uptake currents similar in amplitude to those under control conditions.

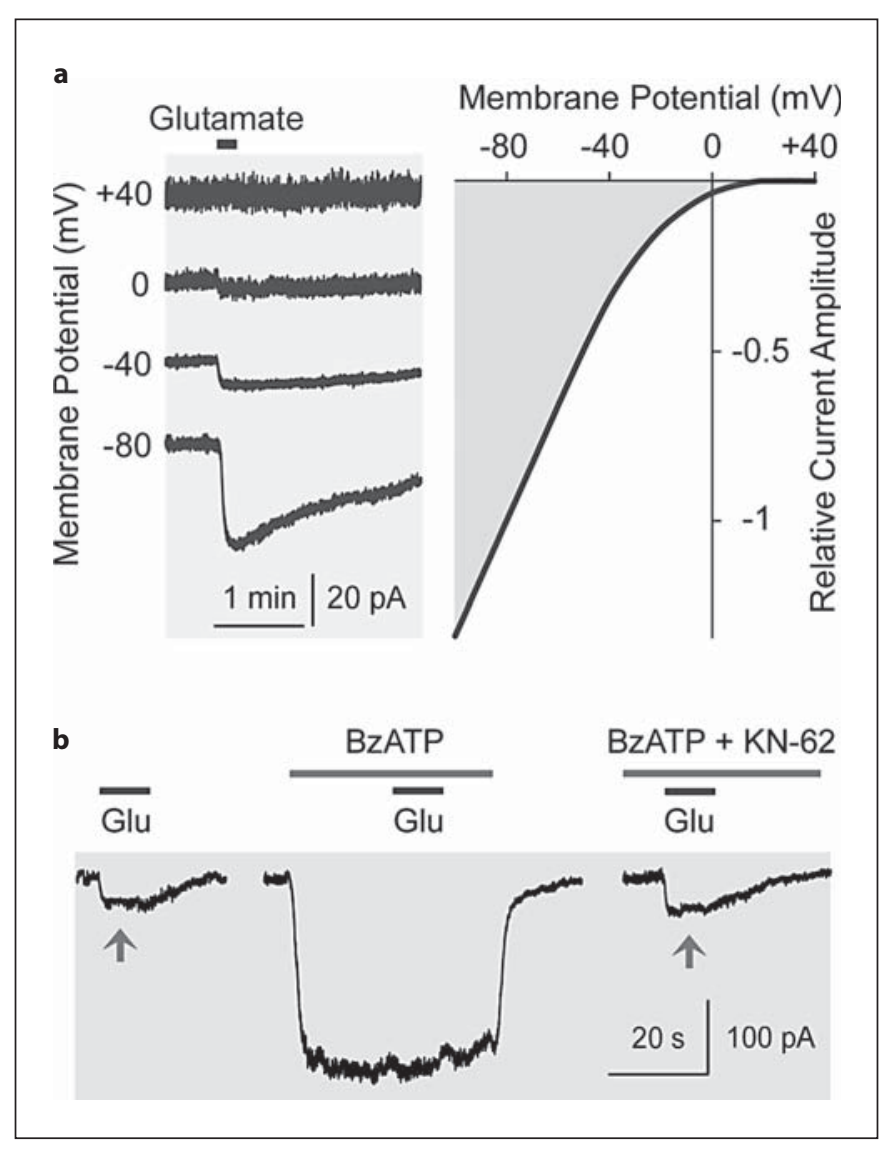

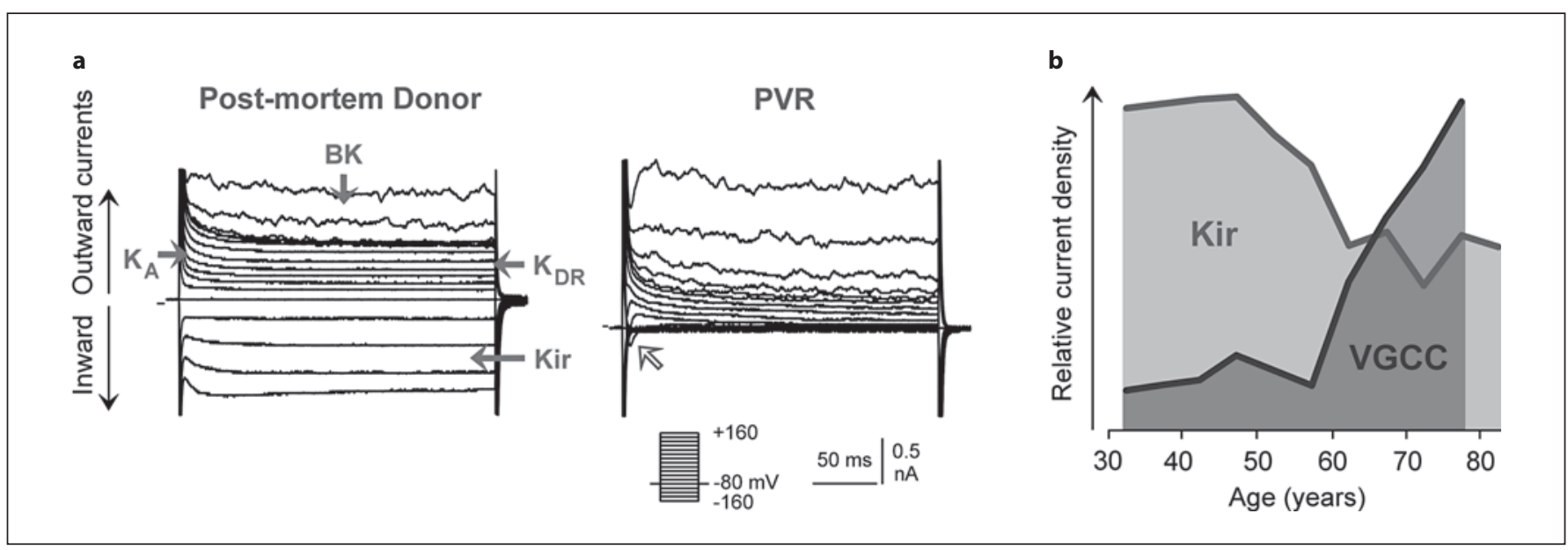

Fig. 5. Age- and disease-related alterations in the membrane conductance of human Müller cells. a Four different types of potassium currents can be recorded in Müller cells from postmortem donors without apparent eye diseases (left): BK, currents mediated by BK channels; fast transient (A-type) potassium currents $\left(\mathrm{K}_{\mathrm{A}}\right)$; delayed rectifying potassium currents $\left(\mathrm{K}_{\mathrm{DR}}\right)$ and Kir currents. Müller cells obtained from patients with proliferative vitreoretinopathy (PVR) display an almost complete absence of Kir currents. The inward potassium currents (evoked by membrane hyperpolarization from a holding potential of $-80 \mathrm{mV}$ ) are depicted downwardly. The outward potassium currents (evoked by membrane depolarization) are depicted upwardly. The white arrow indicates transient inward currents through voltage-gated sodium channels. b Age-dependent alterations in the densities of Kir and L-type voltage-gated calcium channel (VGCC) currents in human Müller cells. While Kir currents display an age-dependent decrease, currents through L-type calcium channels increase in the course af aging. 


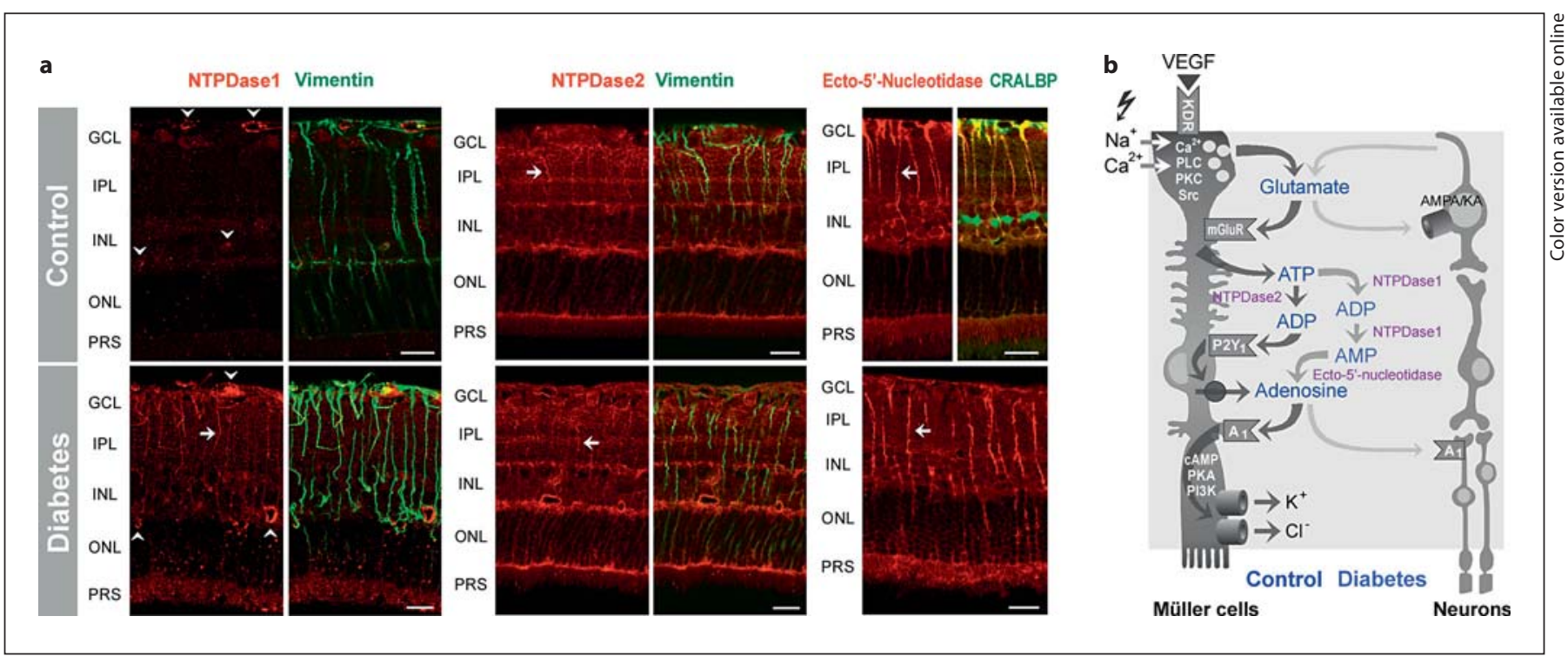

Fig. 6. The source of extracellular adenosine alters in experimental diabetic retinopathy. a Immunolocalization of nucleotide-degrading ectoenzymes in retinal slices from control (above) and diabetic rats (below). The slices were stained against NTPDase1, NTPDase2 and ecto-5'-nucleotidase, respectively (red). The slices were counterstained against the glial proteins vimentin and cellular retinaldehyde-binding protein (CRALBP), respectively (green). Arrows: Müller cell fibers crossing the inner plexiform layer (IPL). Arrowheads: blood vessels. Note that the immunolabeling of NTPDase1 is restricted to the blood vessels in the control retina, while in the retina of the diabetic animal, NTPDase1 immunoreactivity is also localized to Müller cell fibers. GCL $=$ Ganglion cell layer; INL = inner nuclear layer; $\mathrm{ONL}=$ outer nuclear layer; PRS = photoreceptor segments. Scale bars: $20 \mu \mathrm{m}$. b Scheme of the autocrine glutamatergic-purinergic signaling cascade involved in the VEGF-induced inhibition of Müller cell swelling.
Activation of KDR/flk-1 by VEGF evokes exocytotic release of glutamate from Müller cells. Glutamate activates metabotropic glutamate receptors (mGluRs), which results in ATP release from Müller cells. ATP is extracellularly converted to ADP by NTPDase 2 that activates $\mathrm{P}_{2} \mathrm{Y}_{1}$, resulting in nucleoside transporter-mediated release of adenosine. Activation of $\mathrm{A}_{1}$ adenosine receptors opens potassium and chloride channels. Neuron-derived glutamate may activate the volume-regulatory signaling cascade in dependence on neuronal activity. Müller cell-derived glutamate and adenosine may also activate neuronal $\alpha$-amino-3-hydroxy-5methyl-4-isoxazolepropionic acid/kainate (AMPA/KA) and $\mathrm{A}_{1}$ receptors, resulting in stimulation and inhibition, respectively, of neuronal activity. In the retinal parenchyma of diabetic rats, NTPDase1 (which hydrolyses ATP and ADP about equally well) is upregulated, and extracellular formation of adenosine contributes to the inhibitory effect of glutamate and ATP on swelling.

\section{Contribution to Vascular Edema}

Vascular leakage caused by opening of the tight junctions between vascular endothelial cells and increased vesicular transport of serum proteins across the vascular endothelia is an important pathogenic mechanism of retinal edema [201]. Retinal capillaries are closely ensheathed by glial processes [7]. Usually, Müller cells enhance the barrier function of vascular endothelia [202204] by the secretion of factors such as pigment epithelium-derivedfactor(PEDF), thrombospondin-1, neurturin, and GDNF [205-208]. PEDF expression in Müller cells is regulated by soluble factors released from vascular endothelial cells [209].
Vascular endothelial growth factor (VEGF) is the major hypoxia-induced vessel-permeabilizing factor [210213]. In addition, inflammatory factors such as tumor necrosis factor, interleukin-1 $\beta$, and prostaglandins enhance the permeability of retinal vessels $[212,214,215]$. In response to hypoxia, inflammation and glucose deprivation, Müller cells produce vessel-permeabilizing factors such as VEGF and tumor necrosis factor [204, 206, 216221]. Posterior vitreous detachment from the retina is associated with mechanical stress on Müller cells, which results in the release of vessel-permeabilizing factors including bFGF $[85,87]$. Müller cells are also a source of matrix metalloproteinases [94, 221, 222], which (among others) degrade occludin, a tight-junction protein [223]. High glucose stimulates the production of proteinases [223]. 


\section{Dysfunctional Fluid Clearance and Cytotoxic Edema}

Edema is caused by an imbalance between fluid influx from the blood into retinal tissue and fluid clearance from the tissue $[39,224]$. Edema develops by vascular leakage and/or neuronal and glial cell swellings (cytotoxic edema) [39, 224]. Fluid clearance is usually mediated by osmotic water transport through glial and pigment epithelial cells which is coupled to the transport of osmolytes, in particular potassium and chloride ions [39, 197, $225,226]$. The coupled potassium and water transport through Müller cells is facilitated by Kir channels and water channels, in particular aquaporin-4 (fig. 1b) [34, 197, 227-229].

Because water transport through Müller cells is coupled to potassium currents [197], dysfunction of Kir4.1 channels as observed under pathological conditions (fig. 1d, 2, 3a, b, d, 5) should also disturb transcellular water transport $[39,224]$. Indeed, Müller cell bodies in slices of diseased retinas swell upon hypoosmotic challenge which is not observed in control retinal tissues (fig. 1e, 3c) [27, 29, 30, 34-36, 38, 138, 170, 171, 174, 177, 230-237]. Because Müller cells lack functional Kir4.1 channels, they are not capable of rapidly releasing potassium which otherwise would compensate the osmotic gradient between the Müller cell interior and the hypoosmotic environment $[27,39,224]$. This results in water influx and cellular swelling. However, Müller cells are still capable to take up potassium through Kir2.1 channels, which are not altered in their expression after ischemia (fig. 3d) [32]. This may result in a potassium accumulation within the cells and, thus, in increased intracellular osmotic pressure $[27,39$ ] which (in situ) draws water from fluid-filled spaces outside the neuroretina (blood, vitreous) into the perivascular and endfoot regions of Müller cells, resulting in Müller cell swelling. Thus, dysfunctional water clearance and possibly Müller cell swelling contribute to the development of edema. The age-dependent decrease in potassium conductance of human Müller cells (fig. 5b) [200] may contribute to the higher incidence of retinal edema in the elderly. Triamcinolone acetonide inhibits Müller cell swelling by inducing endogenous adenosine signaling and opening of ion channels in the Müller cell membrane [230]; the latter might re-establish the fluid clearance function of Müller cells when the Kir4.1 channels are dysfunctional [224].

Müller cells might also contribute to the resolution of edema as observed in experimental retinal light injury $[34,238]$. Excessive light causes damage to the retinal pigment epithelium and induces apoptotic death of photore- ceptor cells (fig. 1a) [34, 238-241]. Both result in the development of local edema in the outer retina. Apoptotic cells undergo shrinkage, which is mediated by channeland transporter-mediated efflux of ions (potassium and chloride) and water [242-245]. Usually, the expression of aquaporin- 4 in the outer nuclear layer is faint and strongly increases after light injury (fig. 1b) [34, 238]. The upregulation of aquaporin-4 may support the resolution of edema in the outer retina. However, downregulation of Kir4.1 (fig. 1d, 2) and dysregulation of transcellular water transport (fig. 1e) may contribute to secondary inner retinal tissue degeneration, which is often observed after light injury (fig. 2) [34, 246, 247].

\section{Dysfunctional Purinergic Regulation of Müller Cell Volume}

Müller cells possess an endogenous purinergic signaling cascade that inhibits osmotic swelling $[138,170-174$, 230]. This signaling cascade involves the release of ATP and adenosine, and the consecutive activation of purinergic $\mathrm{P}_{2} \mathrm{Y}_{1}$ and $\mathrm{A}_{1}$ adenosine receptors (fig. $6 \mathrm{~b}$ ) $[138,170$, 171]. Activation of $A_{1}$ receptors induces the opening of chloride and potassium channels; ion efflux equalizes the osmotic gradient across the plasma membrane and thus prevents cellular swelling.

The release of ATP from Müller cells can be induced either by glutamate (acting at metabotropic glutamate receptors; fig. 6b) or by osmotic stress, which mechanically perturbs the plasma membrane [172-174]. While Müller cells from control retinas do not swell under hypoosmotic conditions, Müller cells in slices of diseased retinas rapidly swell (fig. 1e, 3c). This suggests that the osmotic/ mechanical release of ATP is abrogated under pathological conditions. Abrogation of the osmotic ATP release prevents an excess release of ATP from Müller cells which has neuroprotective effects under conditions associated with mechanical stress like retinal detachment and glaucoma (see above). Abrogation of the osmotic/ mechanical ATP release also has glioprotective effects. Because $\mathrm{P}_{2} \mathrm{Y}_{1}$ receptors are the major purinergic receptor subtype that induces calcium responses in Müller cells [248-250], abrogation of the ATP release might protect the cells from cytotoxic calcium overload. The probability that Müller cells become dysfunctional and reactive is increased in the course of aging because an increase in the density of voltage-gated calcium channels (fig. 5b) [251] facilitates calcium-dependent mechanisms of gliosis in the elderly. 


\section{Systemic Factors That Induce Müller Cell Swelling}

Vascular edema is oftenly accompanied by retinal cell swelling, in particular, Müller cells [252-254]. Increased vascular permeability is associated with the extravasation of albumin; in the presence of a hypoosmotic environment, albumin induces Müller cell swelling [255]. Thus, extravasated albumin may represent one factor linking vascular leakage, Müller cell swelling and dysregulation of retinal fluid clearance. Other blood-derived factors, like thrombin and glutamate, may be involved (see above). Müller cell swelling might also be induced by systemic osmotic imbalance, e.g. by a decrease in blood osmolarity [256] due to hyponatremia or hypoalbuminemia in cases of renal and hepatic failure. In hepatic retinopathy, which is caused by liver failure resulting in increased levels of blood ammonia [257], the pathological alterations in the retina are primarily found in glial cells (mitochondrial and cellular swelling, vacuolization and necrosis) [258-260]. The swelling-inducing effect of ammonia is accelerated by hypoosmolarity [237], suggesting that hyponatremia (predictive of mortality in end-stage liver disease $[261,262]$ ) acts synergistically with hyperammonemia in inducing cytotoxic swelling of glial cells.

\section{Müller Stem Cells}

Müller cells of the mature retina were suggested to represent latent neural stem cells [263-267]. After retinal injury, a population of Müller cells dedifferentiates to cells with properties similar to pluripotent retinal progenitor/ stem cells and express neuronal and photoreceptor proteins [268-273]. However, the neuron-regenerating potential of Müller cells in situ is very restricted. Attempts to facilitate the neurogenic program of Müller cells, e.g. by transdifferentiation of cultured Müller cells, are ongoing $[265,270,273-280]$.

Due to their potential for generating neural progenitor/stem cells, Müller cells will have a great impact on future cell-based therapeutic approaches. However, the molecular signals that trigger the neurogenic process remain to be explored to guide the direction of differentiation and to increase the number of newly generated neurons. Surgically removed epiretinal membranes represent one putative source of Müller stem cells [281]; the use of such cells will avoid immunological complications after cell transplantation. The slow progress of this approach underlines that a better understanding of the gliotic mechanisms is essential for the development of efficient therapeutic strategies aimed at increasing the protective and regenerative properties of reactive Müller cells and decreasing their toxicity.

\section{Acknowledgements}

Some of the work presented in this review was conducted with grants from the Deutsche Forschungsgemeinschaft (RE 849/12; GRK 1097/1; KO 1547/6) and the German Federal Ministry of Education and Research (BMBF; DLR/01GZ0703).

\section{Disclosure Statement}

Both authors have no conflicts of interest to declare.

\section{References}

1 Bringmann A, Pannicke T, Grosche J, Francke M, Wiedemann P, Skatchkov SN, Osborne NN, Reichenbach A: Müller cells in the healthy and diseased retina. Prog Retin Eye Res 2006;25:397-424.

-2 Stone J, Itin A, Alon T, Pe'er J, Gnessin H, Chan-Ling T, Keshet E: Development of retinal vasculature is mediated by hypoxia-induced vascular endothelial growth factor (VEGF) expression by neuroglia. J Neurosci 1995; 15:4738-4747.

3 Provis JM: Development of the primate retinal vasculature. Prog Retin Eye Res 2001;20: 799-821.
4 Stone J, Dreher Z: Relationship between astrocytes, ganglion cells and vasculature of the retina. J Comp Neurol 1987;255:35-49.

5 Reichenbach A, Schippel K, Schümann R, Hagen E: Ultrastructure of rabbit retinal nerve fibre layer - neuro-glial relationships, myelination, and nerve fibre spectrum. J Hirnforsch 1988;29:481-491.

6 Reichenbach A, Robinson SR: Phylogenetic constraints on retinal organization and development: an Haeckelian perspective. Prog Retin Eye Res 1995;15:139-171.

7 Reichenbach A, Bringmann A: Müller Cells in the Healthy and Diseased Retina. New York, Springer, 2010.
8 Bringmann A, Pannicke T, Biedermann B, Francke M, Iandiev I, Grosche J, Wiedemann $\mathrm{P}$, Albrecht J, Reichenbach A: Role of retinal glial cells in neurotransmitter uptake and metabolism. Neurochem Int 2009;54:143160.

9 Franze K, Grosche J, Skatchkov SN, Schinkinger S, Foja C, Schild D, Uckermann O, Travis K, Reichenbach A, Guck J: Müller cells are living optical fibers in the vertebrate retina. Proc Natl Acad Sci USA 2007;104: 8287-8292. 
$>10$ Lu Y-B, Franze K, Seifert G, Steinhäuser C, 22 Muniz A, Villazana-Espinoza ET, Hatch AL, Kirchhoff F, Wolburg H, Guck J, Janmey P, Wei E-Q, Käs J, Reichenbach A: Viscoelastic properties of individual glial cells and neurons in the CNS. Proc Natl Acad Sci USA 2006;103:17759-17764.

11 Bringmann A, Iandiev I, Pannicke T, Wurm A, Hollborn M, Wiedemann P, Osborne NN, Reichenbach A: Cellular signaling and factors involved in Müller cell gliosis: neuroprotective and detrimental effects. Prog Retin Eye Res 2009;28:423-451.

12 Bignami A, Dahl D: The radial glia of Müller in the rat retina and their response to injury: an immunofluorescence study with antibodies to the glial fibrillary acidic (GFA) protein. Exp Eye Res 1979;28:63-69.

$\checkmark 13$ Lewis GP, Fisher SK: Up-regulation of glial fibrillary acidic protein in response to retinal injury: its potential role in glial remodeling and a comparison to vimentin expression. Int Rev Cytol 2003;230:263-290.

-14 Lewis GP, Erickson PA, Guerin CJ, Anderson $\mathrm{DH}$, Fisher SK: Changes in the expression of specific Müller cell proteins during longterm retinal detachment. Exp Eye Res 1989; 49:93-111.

15 Lewis GP, Mervin K, Valter K, Maslim J, Kappel PJ, Stone J, Fisher S: Limiting the proliferation and reactivity of retinal Müller cells during experimental retinal detachment: the value of oxygen supplementation. Am J Ophthalmol 1999;128:165-172.

16 Gorovits R, Yakir A, Fox LE, Vardimon L: Hormonal and non-hormonal regulation of glutamine synthetase in the developing neural retina. Mol Brain Res 1996;43:321-329.

$\checkmark 17$ Francke M, Pannicke T, Biedermann B, Faude F, Wiedemann P, Reichenbach A, Reichelt W: Loss of inwardly rectifying potassium currents by human retinal glial cells in diseases of the eye. Glia 1997;20:210-218.

$\checkmark 18$ Francke M, Faude F, Pannicke T, Bringmann A, Eckstein P, Reichelt W, Wiedemann P, Reichenbach A: Electrophysiology of rabbit Müller (glial) cells in experimental retinal detachment and PVR. Invest Ophthalmol Vis Sci 2001;42:1072-1079.

19 Francke M, Weick M, Pannicke T, Uckermann O, Grosche J, Goczalik I, Milenkovic I, Uhlmann S, Faude F, Wiedemann P, Reichenbach A, Bringmann A: Up-regulation of extracellular ATP-induced Müller cell responses in a dispase model of proliferative vitreoretinopathy. Invest Ophthalmol Vis Sci 2002;43:870-881.

20 Reichelt W, Pannicke T, Biedermann B, Francke M, Faude F: Comparison between functional characteristics of healthy and pathological human retinal Müller glial cells. Surv Ophthalmol 1997;42:S105-S117.

21 Kruchkova Y, Ben-Dror I, Herschkovitz A, David M, Yayon A, Vardimon L: Basic fibroblast growth factor: a potential inhibitor of glutamine synthetase expression in injured neural tissue. J Neurochem 2001;77:16411649. Trevino SG, Allen DM, Tsin AT: A novel cone visual cycle in the cone-dominated retina. Exp Eye Res 2007;85:175-184.

23 Bringmann A, Francke M, Pannicke T, Biedermann B, Faude F, Enzmann V, Wiedemann P, Reichelt W, Reichenbach A: Human Müller glial cells: altered potassium channel activity in proliferative vitreoretinopathy. Invest Ophthalmol Vis Sci 1999;40:33163323.

24 Bringmann A, Pannicke T, Moll V, Milenkovic I, Faude F, Enzmann V, Wolf S, Reichenbach A: Upregulation of $\mathrm{P}_{2} \mathrm{X}_{7}$ receptor currents in Müller glial cells during proliferative vitreoretinopathy. Invest Ophthalmol Vis Sci 2001;42:860-867.

25 Bringmann A, Pannicke T, Uhlmann S, Kohen L, Wiedemann P, Reichenbach A: Membrane conductance of Müller glial cells in proliferative diabetic retinopathy. Can J Ophthalmol 2002;37:221-227.

26 Uhlmann S, Bringmann A, Uckermann O, Pannicke T, Weick M, Ulbricht E, Goczalik I, Reichenbach A, Wiedemann P, Francke M: Early glial cell reactivity in experimental retinal detachment: effect of suramin. Invest Ophthalmol Vis Sci 2003;44:4114-4122.

27 Pannicke T, Iandiev I, Uckermann O, Biedermann B, Kutzera F, Wiedemann P, Wolburg H, Reichenbach A, Bringmann A: A potassium channel-linked mechanism of glial cell swelling in the postischemic retina. Mol Cell Neurosci 2004;26:493-502.

28 Pannicke T, Uckermann O, Iandiev I, Biedermann B, Wiedemann P, Perlman I, Reichenbach A, Bringmann A: Altered membrane physiology in Müller glial cells after transient ischemia of the rat retina. Glia 2005;50:1-11.

29 Pannicke T, Uckermann O, Iandiev I, Wiedemann P, Reichenbach A, Bringmann A: Ocular inflammation alters swelling and membrane characteristics of rat Müller glial cells. J Neuroimmunol 2005;161:145-154.

30 Pannicke T, Iandiev I, Wurm A, Uckermann $\mathrm{O}$, vom Hagen F, Reichenbach A, Wiedemann P, Hammes H-P, Bringmann A: Diabetes alters osmotic swelling characteristics and membrane conductance of glial cells in rat retina. Diabetes 2006;55:633-639.

- 31 Uckermann O, Uhlmann S, Pannicke T, Francke M, Gamsalijew R, Makarov F, Ulbricht E, Wiedemann P, Reichenbach A, Osborne NN, Bringmann A: Ischemia-reperfusion causes exudative detachment of the rabbit retina. Invest Ophthalmol Vis Sci 2005; 46:2592-2600.

32 Iandiev I, Tenckhoff S, Pannicke T, Biedermann B, Hollborn M, Wiedemann P, Reichenbach A, Bringmann A: Differential regulation of Kir4.1 and Kir2.1 expression in the ischemic rat retina. Neurosci Lett 2006;396: 97-101.
33 Iandiev I, Uckermann O, Pannicke T, Wurm A, Pietsch U-C, Reichenbach A, Wiedemann P, Bringmann A, Uhlmann S: Glial cell reactivity in a porcine model of retinal detachment. Invest Ophthalmol Vis Sci 2006;47: 2161-2171.

34 Iandiev I, Wurm A, Hollborn M, Wiedemann P, Grimm C, Remé CE, Reichenbach A, Pannicke T, Bringmann A: Müller cell response to blue light injury of the rat retina. Invest Ophthalmol Vis Sci 2008;49:35593567.

35 Wurm A, Pannicke T, Iandiev I, Bühner E, Pietsch UC, Reichenbach A, Wiedemann P, Uhlmann S, Bringmann A: Changes in membrane conductance play a pathogenic role in osmotic glial cell swelling in detached retinas. Am J Pathol 2006;169:1990-1998.

- 36 Wurm A, Iandiev I, Uhlmann S, Wiedemann P, Reichenbach A, Bringmann A, Pannicke T: Effects of ischemia-reperfusion on physiological properties of Müller glial cells in the porcine retina. Invest Ophthalmol Vis Sci 2011;52:3360-3367.

- 37 Ulbricht E, Pannicke T, Hollborn M, Raap M, Goczalik I, Iandiev I, Härtig W, Uhlmann S, Wiedemann P, Reichenbach A, Bringmann A, Francke M: Proliferative gliosis causes mislocation and inactivation of inwardly rectifying $\mathrm{K}^{+}$(Kir) channels in rabbit retinal glial cells. Exp Eye Res 2008;86:305313.

38 Rehak M, Hollborn M, Iandiev I, Pannicke T, Karl A, Wurm A, Kohen L, Reichenbach A, Wiedemann P, Bringmann A: Retinal gene expression and Müller cell responses after branch retinal vein occlusion in the rat. Invest Ophthalmol Vis Sci 2009;50:2359-2367.

39 Bringmann A, Reichenbach A, Wiedemann P: Pathomechanisms of cystoid macular edema. Ophthalmic Res 2004;36:241-249.

40 Nakazawa T, Matsubara A, Noda K, Hisatomi T, She H, Skondra D, Miyahara S, Sobrin L, Thomas KL, Chen DF, Grosskreutz CL, Hafezi-Moghadam A, Miller JW: Characterization of cytokine responses to retinal detachment in rats. Mol Vis 2006;12:867-878.

41 Hollborn M, Francke M, Iandiev I, Bühner E, Foja C, Kohen L, Reichenbach A, Wiedemann P, Bringmann A, Uhlmann S: Early activation of inflammation- and immune response-related genes after experimental detachment of the porcine retina. Invest Ophthalmol Vis Sci 2008;49:1262-1273.

-42 Nakazawa T, Hisatomi T, Nakazawa C, Noda K, Maruyama K, She H, Matsubara A, Miyahara S, Nakao S, Yin Y, Benowitz L, HafeziMoghadam A, Miller JW: Monocyte chemoattractant protein 1 mediates retinal detachment-induced photoreceptor apoptosis. Proc Natl Acad Sci USA 2007; 104:24252430.

-43 Neufeld AH, Kawai S, Das S, Vora S, Gachie E, Connor JR, Manning PT: Loss of retinal ganglion cells following retinal ischemia: the role of inducible nitric oxide synthase. Exp Eye Res 2002;75:521-528. 
-44 Nakazawa T, Takeda M, Lewis GP, Cho KS, Jiao J, Wilhelmsson U, Fisher SK, Pekny M, Chen DF, Miller JW: Attenuated glial reactions and photoreceptor degeneration after retinal detachment in mice deficient in glial fibrillary acidic protein and vimentin. Invest Ophthalmol Vis Sci 2007;48:2760-2768.

-45 Wen R, Song Y, Cheng T, Matthes MT, Yasumura D, LaVail MM, Steinberg RH: Injury-induced upregulation of bFGF and CNTF mRNAs in the rat retina. J Neurosci 1995;15: 7377-7385.

-46 Harada T, Harada C, Nakayama N, Okuyama S, Yoshida K, Kohsaka S, Matsuda H, Wada $\mathrm{K}$ : Modification of glial-neuronal cell interactions prevents photoreceptor apoptosis during light-induced retinal degeneration. Neuron 2000;26:533-541.

-47 Hauck SM, Kinkl N, Deeg CA, Swiatek-de Lange M, Schöffmann S, Ueffing M: GDNF family ligands trigger indirect neuroprotective signaling in retinal glial cells. Mol Cell Biol 2006;26:2746-2757.

48 Harada C, Harada T, Quah HMA, Maekawa F, Yoshida K, Ohno S, Wada K, Parada LF, Tanaka K: Potential role of glial cell line-derived neurotrophic factor receptors in Müller glial cells during light-induced retinal degeneration. Neuroscience 2003;122:229-235.

-49 Delyfer MN, Simonutti M, Neveux N, Léveillard T, Sahel JA: Does GDNF exert its neuroprotective effects on photoreceptors in the $r d 1$ retina through the glial glutamate transporter GLAST? Mol Vis 2005;11:677-687.

50 Koeberle PD, Bähr M: The upregulation of GLAST-1 is an indirect antiapoptotic mechanism of GDNF and neurturin in the adult CNS. Cell Death Differ 2008;15:471-483.

-51 Liu C, Peng M, Laties AM, Wen R: Preconditioning with bright light evokes a protective response against light damage in the rat retina. J Neurosci 1998;18:1337-1344.

-52 Chu Y, Humphrey MF, Alder VV, Constable IJ: Immunocytochemical localization of basic fibroblast growth factor and glial fibrillary acidic protein after laser photocoagulation in the Royal College of Surgeons rat. Aust N Z J Ophthalmol 1998;26:87-96.

53 Woodford BJ, Tso MO, Lam KW: Reduced and oxidized ascorbates in guinea pig retina under normal and light-exposed conditions. Invest Ophthalmol Vis Sci 1983;24:862-867.

-54 Ulyanova T, Szél A, Kutty RK, Wiggert B, Caffé AR, Chader GJ, van Veen T: Oxidative stress induces heme oxygenase-1 immunoreactivity in Müller cells of mouse retina in organ culture. Invest Ophthalmol Vis Sci 2001; 42:1370-1374.

55 Miyahara T, Kikuchi T, Akimoto M, Kurokawa T, Shibuki H, Yoshimura N: Gene microarray analysis of experimental glaucomatous retina from cynomologous monkey. Invest Ophthalmol Vis Sci 2003;44:4347-4356.

56 Chen L, Dentchev T, Wong R, Hahn P, Wen $\mathrm{R}$, Bennett J, Dunaief JL: Increased expression of ceruloplasmin in the retina following photic injury. Mol Vis 2003;9:151-158.
Arai-Gaun S, Katai N, Kikuchi T, Kurokawa T, Ohta K, Yoshimura N: Heme oxygenase-1 induced in Müller cells plays a protective role in retinal ischemia-reperfusion injury in rats. Invest Ophthalmol Vis Sci 2004;45: 4226-4232.

58 Frenzel J, Richter J, Eschrich K: Pyruvate protects glucose-deprived Müller cells from nitric oxide-induced oxidative stress by radical scavenging. Glia 2005;52:276-288.

59 Francke M, Makarov F, Kacza J, Wendt S, Gärtner U, Faude F, Wiedemann P, Reichenbach A: Retinal pigment epithelium melanin granules are phagocytozed by Müller glial cells in experimental retinal detachment. J Neurocytol 2001;30:131-136.

60 Flanagan LA, Ju YE, Marg B, Osterfield M, Janmey PA: Neurite branching on deformable substrates. Neuroreport 2002;13:24112415.

61 Lu YB, Iandiev I, Hollborn M, Körber N, Ulbricht E, Hirrlinger PG, Pannicke T, Wei EQ, Bringmann A, Wolburg $\mathrm{H}$, Wilhelmsson $\mathrm{U}$, Pekny M, Wiedemann P, Reichenbach A, Käs JA: Reactive glial cells: increased stiffness correlates with increased intermediate filament expression. FASEB J 2011;25:624-631.

62 Lundkvist A, Reichenbach A, Betsholtz C, Carmeliet P, Wolburg H, Pekny M: Under stress, the absence of intermediate filaments from Müller cells in the retina has structural and functional consequences. J Cell Sci 2004; 117:3481-3488

63 Chaitin MH, Wortham HS, Brun-Zinkernagel AM: Immunocytochemical localization of CD44 in the mouse retina. Exp Eye Res 1994;58:359-366.

64 Chaitin MH, Ankrum MT, Wortham HS: Distribution of CD44 in the retina during development and the $r d s$ degeneration. Dev Brain Res 1996;94:92-98.

65 Kuhrt H, Härtig W, Grimm D, Faude F, Kasper M, Reichenbach A: Changes in CD44 and ApoE immunoreactivities due to retinal pathology of man and rat. J Hirnforsch 1997; 38:223-229.

66 Krishnamoorthy R, Agarwal N, Chaitin $\mathrm{MH}$ : Upregulation of CD44 expression in the retina during the $r d s$ degeneration. Mol Brain Res 2000;77:125-130.

67 Inatani $\mathrm{M}$, Tanihara $\mathrm{H}$, Oohira $\mathrm{A}$, Honjo M, Kido N, Honda Y: Upregulated expression of neurocan, a nervous tissue specific proteoglycan, in transient retinal ischemia. Invest Ophthalmol Vis Sci 2000;41:2748-2754.

68 Sellés-Navarro I, Ellezam B, Fajardo R, Latour M, McKerracher L: Retinal ganglion cell and nonneuronal cell responses to a microcrush lesion of adult rat optic nerve. Exp Neurol 2001;167:282-289.

69 Zhang Y, Rauch U, Perez MT: Accumulation of neurocan, a brain chondroitin sulfate proteoglycan, in association with the retinal vasculature in RCS rats. Invest Ophthalmol Vis Sci 2003;44:1252-1261.
70 Fisher SK, Lewis GP: Müller cell and neuronal remodeling in retinal detachment and reattachment and their potential consequences for visual recovery: a review and reconsideration of recent data. Vision Res 2003;43: 887-897.

71 Silver J: Inhibitory molecules in development and regeneration. J Neurol 1994; 242:S22-S24.

72 Canning DR, Höke A, Malemud CJ, Silver J: A potent inhibitor of neurite outgrowth that predominates in the extracellular matrix of reactive astrocytes. Int J Dev Neurosci 1996; 14:153-175.

73 Fawcett JW, Asher RA: The glial scar and central nervous system repair. Brain Res Bull 1999;49:377-391.

74 Ponta H, Sherman L, Herrlich PA: CD44: from adhesion molecules to signalling regulators. Nat Rev Mol Cell Biol 2003;4:33-45.

75 Marc RE, Jones BW, Watt CB, Strettoi E: Neural remodeling in retinal degeneration. Prog Retin Eye Res 2003;22:607-655.

76 Charteris DG, Sethi CS, Lewis GP, Fisher SK: Proliferative vitreoretinopathy - developments in adjunctive treatment and retinal pathology. Eye 2002;16:369-374.

77 Jones BW, Watt CB, Frederick JM, Baehr W, Chen CK, Levine EM, Milam AH, Lavail MM, Marc RE: Retinal remodeling triggered by photoreceptor degenerations. J Comp Neurol 2003;464:1-16

78 Sullivan R, Penfold P, Pow DV: Neuronal migration and glial remodeling in degenerating retinas of aged rats and in nonneovascular AMD. Invest Ophthalmol Vis Sci 2003;44: 856-865.

79 Lewis GP, Talaga KC, Linberg KA, Avery RL, Fisher SK: The efficacy of delayed oxygen therapy in the treatment of experimental retinal detachment. Am J Ophthalmol 2004; 137:1085-1095.

80 Sethi CS, Lewis GP, Fisher SK, Leitner WP, Mann DL, Luthert PJ, Charteris DG: Glial remodeling and neural plasticity in human retinal detachment with proliferative vitreoretinopathy. Invest Ophthalmol Vis Sci 2005;46:329-342.

81 Lesnik Oberstein SY, Lewis GP, Chapin EA, Fisher SK: Ganglion cell neurites in human idiopathic epiretinal membranes. Br J Ophthalmol 2008;92:981-985.

82 Pardue MT, Stubbs EB Jr, Perlman JI, Narfström K, Chow AY, Peachey NS: Immunohistochemical studies of the retina following long-term implantation with subretinal microphotodiode arrays. Exp Eye Res 2001;73: 333-343.

83 Charteris DG, Downie J, Aylward GW, Sethi C, Luthert P: Intraretinal and periretinal pathology in anterior proliferative vitreoretinopathy. Graefes Arch Clin Exp Ophthalmol 2007;245:93-100.

84 Bringmann A, Wiedemann P: Involvement of Müller glial cells in epiretinal membrane formation. Graefes Arch Clin Exp Ophthalmol 2009;247:865-883. 
85 Schubert HD: Cystoid macular edema: the apparent role of mechanical factors. Prog Clin Biol Res 1989;312:277-291.

86 Puro DG: Stretch-activated channels in human retinal Müller cells. Glia 1991;4:456-460.

-87 Lindqvist N, Liu Q, Zajadacz J, Franze K, Reichenbach A: Retinal glial (Müller) cells: sensing and responding to tissue stretch. Invest Ophthalmol Vis Sci 2010;51:1683-1690.

-88 Newman EA: Propagation of intercellular calcium waves in retinal astrocytes and Müller cells. J Neurosci 2001;21:2215-2223.

89 Newman EA: Glial cell inhibition of neurons by release of ATP. J Neurosci 2003;23:16591666.

-90 Puro DG, Roberge F, Chan C-C: Retinal glial cell proliferation and ion channels: a possible link. Invest Ophthalmol Vis Sci 1989;30: 521-529.

-91 Puro DG, Mano T: Modulation of calcium channels in human retinal glial cells by basic fibroblast growth factor: a possible role in retinal pathobiology. J Neurosci 1991;11: 1873-1880.

-92 Kodal H, Weick M, Moll V, Biedermann B, Reichenbach A, Bringmann A: Involvement of calcium-activated potassium channels in the regulation of DNA synthesis in cultured Müller glial cells. Invest Ophthalmol Vis Sci 2000;41:4262-4267.

93 Moll V, Weick M, Milenkovic I, Kodal H, Reichenbach A, Bringmann A: $\mathrm{P} 2 \mathrm{Y}$ receptormediated stimulation of Müller glial DNA synthesis. Invest Ophthalmol Vis Sci 2002; 43:766-773.

94 Milenkovic I, Weick M, Wiedemann P, Reichenbach A, Bringmann A: P2Y receptormediated stimulation of Müller glial cell DNA synthesis: dependence on EGF and PDGF receptor transactivation. Invest Ophthalmol Vis Sci 2003;44:1211-1220.

$\$ 95$ Ambati J, Chalam KV, Chawla DK, D’Angio CT, Guillet EG, Rose SJ, Vanderlinde RE, Ambati BK: Elevated $\gamma$-aminobutyric acid, glutamate, and vascular endothelial growth factor levels in the vitreous of patients with proliferative diabetic retinopathy. Arch Ophthalmol 1997;115:1161-1166.

96 Brooks DE, Garcia GA, Dreyer EB, Zurakowski D, Franco-Bourland RE: Vitreous body glutamate concentrations in dogs with glaucoma. Am J Vet Res 1997;58:864-867.

97 Lieth E, Barber A, Xu B, Dice C, Ratz MJ, Tanase D, Strother JM: Glial reactivity and impaired glutamate metabolism in shortterm experimental diabetic retinopathy. Diabetes 1998;47:815-820.

98 Dkhissi O, Chanut E, Wasowicz M, Savoldelli M, Nguyen-Legros J, Minvielle F, VersauxBotteri C: Retinal TUNEL-positive cells and high glutamate levels in vitreous humor of mutant quail with a glaucoma-like disorder. Invest Ophthalmol Vis Sci 1999;40:990-994.

99 Kowluru RA, Kennedy A: Therapeutic potential of anti-oxidants and diabetic retinopathy. Expert Opin Investig Drugs 2001;10: 1665-1676.
100 Martin KR, Levkovitch-Verbin H, Valenta D, Baumrind L, Pease ME, Quigley HA: Retinal glutamate transporter changes in experimental glaucoma and after optic nerve transection in the rat. Invest Ophthalmol Vis Sci 2002;43:2236-2243.

101 Osborne NN, Casson RJ, Wood JP, Chidlow G, Graham M, Melena J: Retinal ischemia: mechanisms of damage and potential therapeutic strategies. Prog Retin Eye Res 2004; 23:91-147.

102 Delyfer MN, Forster V, Neveux N, Picaud S, Léveillard T, Sahel JA: Evidence for glutamate-mediated excitotoxic mechanisms during photoreceptor degeneration in the rd1 mouse retina. Mol Vis 2005;11:688696.

103 Naskar R, Vorwerk CK, Dreyer EB: Concurrent downregulation of a glutamate transporter and receptor in glaucoma. Invest Ophthalmol Vis Sci 2000;41:19401944.

104 Barnett NL, Pow DV, Bull ND: Differential perturbation of neuronal and glial glutamate transport systems in retinal ischaemia. Neurochem Int 2001;39:291-299.

105 Holcombe DJ, Lengefeld N, Gole GA, Barnett NL: The effects of acute intraocular pressure elevation on rat retinal glutamate transport. Acta Ophthalmol Scand 2008; 86:408-414.

106 White RD, Neal MJ: The uptake of L-glutamate by the retina. Brain Res 1976;111:7993.

107 Ladanyi M, Beaudet A: In-vivo labeling of $(3 \mathrm{H}) \mathrm{D}$-aspartate uptake sites in monkey retina. Cell Tissue Res 1986;243:59-63.

108 Rauen T, Taylor WR, Kuhlbrodt K, Wiessner M: High-affinity glutamate transporters in the rat retina: a major role of the glial glutamate transporter GLAST-1 in transmitter clearance. Cell Tissue Res 1998;291:19-31.

109 Harada T, Harada C, Watanabe M, Inoue Y, Sakagawa T, Nakayama N, Sasaki S, Okuyama S, Watase K, Wada K, Tanaka K: Functions of the two glutamate transporters GLAST and GLT-1 in the retina. Proc Natl Acad Sci USA 1998;95:4663-4666.

110 Pow DV, Barnett NL, Penfold P: Are neuronal transporters relevant in retinal glutamate homeostasis? Neurochem Int 2000;37: 191-198.

111 Barnett NL, Pow DV: Antisense knockdown of GLAST, a glial glutamate transporter, compromises retinal function. Invest Ophthalmol Vis Sci 2000;41:585-591.

112 Rauen T: Diversity of glutamate transporter expression and function in the mammalian retina. Amino Acids 2000;19:53-62.

113 Otori Y, Shimada S, Tanaka K, Ishimoto I, Tano Y, Tohyama M: Marked increase in glutamate-aspartate transporter (GLAST/ GluT-1) mRNA following transient retinal ischemia. Mol Brain Res 1994;27:310-314.
114 Derouiche A, Rauen T: Coincidence of Lglutamate/L-aspartate transporter (GLAST) and glutamine synthetase (GS) immunoreactions in retinal glia: evidence for coupling of GLAST and GS in transmitter clearance. J Neurosci Res 1995;42:131-143.

115 Rauen T, Rothstein JD, Wässle H: Differential expression of three glutamate transporter subtypes in the rat retina. Cell Tissue Res 1996;286:325-336.

116 Lehre KP, Davanger S, Danbolt NC: Localization of the glutamate transporter protein GLAST in rat retina. Brain Res 1997;744: 129-137.

117 Sarthy VP, Pignataro L, Pannicke T, Weick M, Reichenbach A, Harada T, Tanaka K, Marc R: Glutamate transport by retinal Müller cells in glutamate/aspartate transporter-knockout mice. Glia 2005;49:184196

118 Macnab LT, Williams SM, Pow DV: Expression of the exon 3 skipping form of GLAST, GLAST1a, in brain and retina. Neuroreport 2006;17:1867-1870.

119 Brew H, Attwell D: Electrogenic glutamate uptake is a major current carrier in the membrane of axolotl retinal glial cells. Nature 1987;327:707-709.

120 Barbour B, Brew H, Attwell D: Electrogenic glutamate uptake in glial cells is activated by intracellular potassium. Nature 1988; 335:433-435.

121 Barbour B, Brew H, Attwell D: Electrogenic uptake of glutamate and aspartate into glial cells isolated from the salamander (Ambystoma) retina. J Physiol 1991;436:169-193.

122 Sarantis M, Attwell D: Glutamate uptake in mammalian retinal glia is voltage- and potassium-dependent. Brain Res 1990;516: 322-325.

123 Pannicke T, Stabel J, Heinemann U, Reichelt $\mathrm{W}$ : $\alpha$-Aminoadipic acid blocks the $\mathrm{Na}^{+}$-dependent glutamate transport into acutely isolated Müller glial cells from guinea pig retina. Pflügers Arch 1994;429:140-142.

124 Li Q, Puro DG: Diabetes-induced dysfunction of the glutamate transporter in retinal Müller cells. Invest Ophthalmol Vis Sci 2002;43:3109-3116.

125 Asano T, Shigeno T, Johshita H, Usui M, Hanamura T: A novel concept on the pathogenetic mechanism underlying ischaemic brain oedema: relevance of free radicals and eicosanoids. Acta Neurochir Suppl (Wien) 1987;41:85-96

126 Birkle DL, Bazan NG: Light exposure stimulates arachidonic acid metabolism in intact rat retina and isolated rod outer segments. Neurochem Res 1989;14:185-190.

127 Lees GJ: Inhibition of sodium-potassiumATPase: a potentially ubiquitous mechanism contributing to central nervous system neuropathology. Brain Res Rev 1991; $16: 283-380$ 
128 Staub F, Winkler A, Peters J, Kempski O, 142 Puro DG, Stuenkel EL: Thrombin-induced Kachel V, Baethmann A: Swelling, acidosis, and irreversible damage of glial cells from exposure to arachidonic acid in vitro. J Cereb Blood Flow Metab 1994;14:10301039.

129 Bringmann A, Francke M, Pannicke T, Biedermann B, Kodal H, Faude F, Reichelt W, Reichenbach A: Role of glial $\mathrm{K}^{+}$channels in ontogeny and gliosis: a hypothesis based upon studies on Müller cells. Glia 2000;29: 35-44.

130 Pannicke T, Fischer W, Biedermann B, Schädlich H, Grosche J, Faude F, Wiedemann P, Allgaier C, Illes P, Burnstock G, Reichenbach A: $\mathrm{P} 2 \mathrm{X}_{7}$ receptors in Müller glial cells from the human retina. J Neurosci 2000;20:5965-5972.

131 Szatkowski M, Barbour B, Attwell D: Nonvesicular release of glutamate from glial cells by reversed electrogenic glutamate uptake. Nature 1990;348:443-446.

-132 Billups B, Attwell D: Modulation of nonvesicular glutamate release by $\mathrm{pH}$. Nature 1996;379:171-174.

133 Marcaggi P, Hirji N, Attwell D: Release of L-aspartate by reversal of glutamate transporters. Neuropharmacology 2005;49: 843-849.

134 Maguire G, Simko H, Weinreb RN, Ayoub G: Transport-mediated release of endogenous glutamate in the vertebrate retina. Pflügers Arch 1998;436:481-484.

-135 Kato S, Ishita S, Sugawara K, Mawatari K: Cystine/glutamate antiporter expression in retinal Müller glial cells: implications for DL- $\alpha$-aminoadipate toxicity. Neuroscience 1993;57:473-482.

-136 Pow DV, Barnett NL: Aminoadipic acid transport, probing the role of the cystineglutamate antiporter in the retina. Invest Ophthalmol Vis Sci 2000;41:S188.

137 Pow DV: Visualising the activity of the cystine-glutamate antiporter in glial cells using antibodies to aminoadipic acid, a selectively transported substrate. Glia 2001;34: 27-38.

-138 Wurm A, Pannicke T, Wiedemann P, Reichenbach A, Bringmann A: Glial cellderived glutamate mediates autocrine cell volume regulation in the retina: activation by VEGF. J Neurochem 2008;104:386-399.

-139 Muller A, Maurin L, Bonne C: Free radicals and glutamate uptake in the retina. Gen Pharmacol 1998;30:315-318.

$\checkmark 140$ Beretta S, Wood JP, Derham B, Sala G, Tremolizzo L, Ferrarese C, Osborne NN: Partial mitochondrial complex I inhibition induces oxidative damage and perturbs glutamate transport in primary retinal cultures. Relevance to Leber hereditary optic neuropathy (LHON). Neurobiol Dis 2006; 24:308-317.

- 141 Barbour B, Szatkowski M, Ingledew N, Attwell D: Arachidonic acid induces a prolonged inhibition of glutamate uptake into glial cells. Nature 1989;342:918-920. inhibition of potassium currents in human retinal glial (Müller) cells. J Physiol 1995; 485:337-348.

143 Kusaka S, Kapousta-Bruneau NV, Puro DG: Plasma-induced changes in the physiology of mammalian retinal glial cells: role of glutamate. Glia 1999;25:205-215.

144 Gass JD: Stereoscopic atlas of macular diseases: diagnosis and treatment. St Louis, Mosby, 1997.

145 Bill A, Sperber GO: Control of retinal and choroidal blood flow. Eye 1990;4:319-325.

146 Yu DY, Cringle SJ: Retinal degeneration and local oxygen metabolism. Exp Eye Res 2005;80:745-751.

147 Linsenmeier RA: Effects of light and darkness on oxygen distribution and consumption in the cat retina. J Gen Physiol 1986;88: 521-542.

148 Ahmed J, Braun RD, Dunn jr R, Linsenmeier RA: Oxygen distribution in the macaque retina. Invest Ophthalmol Vis Sci 1993;34: 516-521.

149 Pow DV, Crook DK: Immunocytochemical evidence for the presence of high levels of reduced glutathione in radial glial cells and horizontal cells in the rabbit retina. Neurosci Lett 1995; 193:25-28.

150 Reichelt W, Stabel-Burow J, Pannicke T, Weichert H, Heinemann U: The glutathione level of retinal Müller glial cells is dependent on the high-affinity sodium-dependent uptake of glutamate. Neuroscience 1997;77:1213-1224.

151 Schütte M, Werner P: Redistribution of glutathione in the ischemic rat retina. Neurosci Lett 1998;246:53-56.

-152 Huster D, Hjelle OP, Haug FM, Nagelhus EA, Reichelt W, Ottersen OP: Subcellular compartmentation of glutathione and glutathione precursors. A high resolution immunogold analysis of the outer retina of guinea pig. Anat Embryol (Berl) 1998;198: 277-287.

153 Huster D, Reichenbach A, Reichelt W: The glutathione content of retinal Müller (glial) cells: effect of pathological conditions. Neurochem Int 2000;36:461-469.

154 Penn JS, Naash MI, Anderson RE: Effect of light history on retinal antioxidants and light damage susceptibility in the rat. Exp Eye Res 1987;44:779-788.

-155 Stone J, Maslim J, Valter-Kocsi K, Mervin K, Bowers F, Chu Y, Barnett N, Provis J, Lewis G, Fisher SK, Bisti S, Gargini C, Cervetto $L$, Merin S, Peer J: Mechanisms of photoreceptor death and survival in mammalian retina. Prog Retin Eye Res 1999;18: 689-735.

156 Ribelayga C, Mangel SC: A circadian clock and light/dark adaptation differentially regulate adenosine in mammalian retina. J Neurosci 2005;25:215-222.
157 Harada T, Harada C, Nakamura K, Quah HM, Okumura A, Namekata K, Saeki T, Aihara M, Yoshida $\mathrm{H}$, Mitani A, Tanaka K: The potential role of glutamate transporters in the pathogenesis of normal tension glaucoma. J Clin Invest 2007;117:17631770.

158 Kern TS, Kowluru RA, Engerman RL: Abnormalities of retinal metabolism in diabetes or galactosemia: ATPases and glutathione. Invest Ophthalmol Vis Sci 1994;35: 2962-2967.

159 Shelton MD, Kern TS, Mieyal JJ: Glutaredoxin regulates nuclear factor $\kappa-\mathrm{B}$ and intercellular adhesion molecule in Müller cells: model of diabetic retinopathy. J Biol Chem 2007;282:12467-12474.

160 Paasche G, Huster D, Reichenbach A: The glutathione content of retinal Müller (glial) cells: the effects of aging and of application of free-radical scavengers. Ophthalmic Res 1998;30:351-360.

161 Paasche G, Gärtner U, Germer A, Grosche J, Reichenbach A: Mitochondria of retinal Müller (glial) cells: the effects of aging and of application of free radical scavengers. Ophthalmic Res 2000;32:229-236.

162 Larsen AK, Osborne NN: Involvement of adenosine in retinal ischemia. Studies on the rat. Invest Ophthalmol Vis Sci 1996;37: 2603-2611.

163 Roth S, Rosenbaum PS, Osinski J, Park SS, Toledano AY, Li B, Moshfeghi AA: Ischemia induces significant changes in purine concentration in the retina-choroid in rats. Exp Eye Res 1997;65:771-779.

164 Ghiardi GJ, Gidday JM, Roth S: The purine nucleoside adenosine in retinal ischemiareperfusion injury. Vision Res 1999;39: 2519-2535.

165 Sakamoto K, Yonoki Y, Kuwagata M, Saito M, Nakahara T, Ishii K: Histological protection against ischemia-reperfusion injury by early ischemic preconditioning in rat retina. Brain Res 2004;1015:154-160.

166 Housley GD, Bringmann A, Reichenbach A: Purinergic signaling in special senses. Trends Neurosci 2009;32:128-141.

167 Ostwald P, Park SS, Toledano AY, Roth S: Adenosine receptor blockade and nitric oxide synthase inhibition in the retina: impact upon post-ischemic hyperemia and the electroretinogram. Vision Res 1997;37: 3453-3461.

168 Dudek FE, Obenhaus A, Tasker JG: Osmolality-induced changes in extracellular volume alter epileptiform bursts independent of chemical synapses in the rat: importance of non-synaptic mechanisms in hippocampal epileptogenesis. Neurosci Lett 1990; 120:267-270.

169 Chebabo SR, Hester MA, Aitken PG, Somjen GG: Hypotonic exposure enhances synaptic transmission and triggers spreading depression in rat hippocampal tissue slices. Brain Res 1995;695:203-216. 
-170 Uckermann O, Wolf A, Kutzera F, Kalisch F, Beck-Sickinger A, Wiedemann P, Reichenbach A, Bringmann A: Glutamate release by neurons evokes a purinergic inhibitory mechanism of osmotic glial cell swelling in the rat retina: activation by neuropeptide Y. J Neurosci Res 2006;83: 538-550.

-171 Wurm A, Iandiev I, Hollborn M, Wiedemann P, Reichenbach A, Zimmermann $\mathrm{H}$, Bringmann A, Pannicke T: Purinergic receptor activation inhibits osmotic glial cell swelling in the diabetic rat retina. Exp Eye Res 2008;87:385-393.

-172 Wurm A, Lipp S, Pannicke T, Linnertz R, Färber K, Wiedemann P, Reichenbach A, Bringmann A: Involvement of $A_{1}$ adenosine receptors in osmotic volume regulation of retinal glial cells in mice. Mol Vis 2009; 15:1858-1867.

-173 Wurm A, Lipp S, Pannicke T, Linnertz R, Krügel U, Schulz A, Färber K, Zahn D, Grosse J, Wiedemann P, Chen J, Schöneberg T, Illes P, Reichenbach A, Bringmann A: Endogenous purinergic signaling is required for osmotic volume regulation of retinal glial cells. J Neurochem 2010;112: 1261-1272.

-174 Krügel K, Wurm A, Linnertz R, Pannicke T, Wiedemann P, Reichenbach A, Bringmann A: Erythropoietin inhibits osmotic swelling of retinal glial cells by Janus kinase and extracellular signal-regulated kinases1/2mediated release of vascular endothelial growth factor. Neuroscience 2010;165: 1147-1158.

175 Lutty GA, McLeod DS: A new technique for visualization of the human retinal vasculature. Arch Ophthalmol 1992;110:267-276.

-176 McLeod DS, Hasegawa T, Prow T, Merges C, Lutty G: The initial fetal human retinal vasculature develops by vasculogenesis. Dev Dyn 2006;235:3336-3347.

- 177 Iandiev I, Wurm A, Pannicke T, Wiedemann P, Reichenbach A, Robson SC, Zimmermann H, Bringmann A: Ecto-nucleotidases in Müller glial cells of the rodent retina: involvement in inhibition of osmotic cell swelling. Purinergic Signal 2007;3: 423-433.

178 Zimmermann H: Ectonucleotidases: some developments and a note on nomenclature. Drug Dev Res 2001;52:44-56.

-179 Failer BU, Aschrafi A, Schmalzing G, Zimmermann $\mathrm{H}$ : Determination of native oligomeric state and substrate specificity of rat NTPDase1 and NTPDase2 after heterologous expression in Xenopus oocytes. Eur J Biochem 2003;270:1802-1809.

180 Zhang X, Zhang M, Laties AM, Mitchell $\mathrm{CH}$ : Stimulation of $\mathrm{P} 2 \mathrm{X}_{7}$ receptors elevates $\mathrm{Ca}^{2+}$ and kills retinal ganglion cells. Invest Ophthalmol Vis Sci 2005;46:2183-2191.
81 Resta V, Novelli E, Vozzi G, Scarpa C, Caleo M, Ahluwalia A, Solini A, Santini E, Parisi V, Di Virgilio F, Galli-Resta L: Acute retinal ganglion cell injury caused by intraocular pressure spikes is mediated by endogenous extracellular ATP. Eur J Neurosci 2007;25: 2741-2754.

182 Zhang X, Li A, Ge J, Reigada D, Laties AM, Mitchell CH: Acute increase of intraocular pressure releases ATP into the anterior chamber. Exp Eye Res 2007;85:637-643.

183 Reigada D, Lu W, Zhang M, Mitchell CH: Elevated pressure triggers a physiological release of ATP from the retina: possible role for pannexin hemichannels. Neuroscience 2008;157:396-404.

184 Zhang X, Zhang M, Laties AM, Mitchell $\mathrm{CH}$ : Balance of purines may determine life or death of retinal ganglion cells as $\mathrm{A}_{3}$ adenosine receptors prevent loss following $\mathrm{P} 2 \mathrm{X}_{7}$ receptor stimulation. J Neurochem 2006;98:566-575.

185 Steinberg RH, Oakley B II, Niemeyer G: Light-evoked changes in $\left[\mathrm{K}^{+}\right]_{0}$ in retina of intact cat eye. J Neurophysiol 1980;44:897921.

186 Karwoski CJ, Newman EA, Shimazaki H, Proenza LM: Light-evoked increases in extracellular $\mathrm{K}^{+}$in the plexiform layers of amphibian retinas. J Gen Physiol 1985;86:189213.

187 Newman EA, Frambach DA, Odette LL: Control of extracellular potassium levels by retinal glial cell $\mathrm{K}^{+}$siphoning. Science 1984; 225:1174-1175.

188 Karwoski CJ, Lu HK, Newman EA: Spatial buffering of light-evoked potassium increases by retinal Müller (glial) cells. Science 1989;244:578-580.

189 Reichenbach A, Henke A, Eberhardt W, Reichelt W, Dettmer D: $\mathrm{K}^{+}$ion regulation in retina. Can J Physiol Pharmacol 1992; 70:S239-S247.

190 Newman EA: Regional specialization of retinal glial cell membrane. Nature 1984; 309:155-157.

191 Newman EA: Membrane physiology of retinal glial (Müller) cells. J Neurosci 1985;5: 2225-2239.

192 Witkovsky P, Stone S, Ripps H: Pharmacological modification of the light-induced responses of Müller (glial) cells in the amphibian retina. Brain Res 1985;328:111120.

193 Brew H, Gray PT, Mobbs P, Attwell D: Endfeet of retinal glial cells have higher densities of ion channels that mediate $\mathrm{K}^{+}$buffering. Nature 1986;324:466-468.

194 Newman EA: Inward-rectifying potassium channels in retinal glial (Müller) cells. J Neurosci 1993;13:3333-3345.

195 Kofuji P, Ceelen P, Zahs KR, Surbeck LW, Lester HA, Newman EA: Genetic inactivation of an inwardly rectifying potassium channel (Kir4.1 subunit) in mice: phenotypic impact in retina. J Neurosci 2000;20: 5733-5740.
96 Kofuji P, Biedermann B, Siddharthan V, Raap M, Iandiev I, Milenkovic I, Thomzig A, Veh RW, Bringmann A, Reichenbach A: Kir potassium channel subunit expression in retinal glial cells: implications for spatial potassium buffering. Glia 2002;39:292303.

197 Nagelhus EA, Horio Y, Inanobe A, Fujita A, Haug FM, Nielsen S, Kurachi Y, Ottersen OP: Immunogold evidence suggests that coupling of $\mathrm{K}^{+}$siphoning and water transport in rat retinal Müller cells is mediated by a coenrichment of Kir4.1 and AQP4 in specific membrane domains. Glia 1999;26: 47-54.

198 Ishii M, Fujita A, Iwai K, Kusaka S, Higashi K, Inanobe A, Hibino H, Kurachi Y: Differential expression and distribution of Kir5.1 and Kir4.1 inwardly rectifying $\mathrm{K}^{+}$channels in retina. Am J Physiol 2003;285:C260C267.

199 Tenckhoff S, Hollborn M, Kohen L, Wolf S, Wiedemann P, Bringmann A: Diversity of aquaporin mRNA expressed by rat and human retinas. Neuroreport 2005;16:53-56.

200 Bringmann A, Kohen L, Wolf S, Wiedemann P, Reichenbach A: Age-related decrease of potassium currents in human retinal glial (Müller) cells. Can J Ophthalmol 2003;38:464-468.

201 Cunha-Vaz JG, Travassos A: Breakdown of the blood-retinal barriers and cystoid macular edema. Surv Ophthalmol 1984;28: S485-S492.

202 Tout S, Chan-Ling T, Hollander H, Stone J: The role of Müller cells in the formation of the blood-retinal barrier. Neuroscience 1993;55:291-301.

203 Diaz CM, Penfold PL, Provis JM: Modulation of the resistance of a human endothelial cell line by human retinal glia. Aust NZ J Ophthalmol 1998;26:S62-S64.

-204 Tretiach M, Madigan MC, Wen L, Gillies MC: Effect of Müller cell co-culture on in vitro permeability of bovine retinal vascular endothelium in normoxic and hypoxic conditions. Neurosci Lett 2005;378:160-165.

205 Igarashi Y, Chiba H, Utsumi H, Miyajima H, Ishizaki T, Gotoh T, Kuwahara K, Tobioka H, Satoh M, Mori M, Sawada N: Expression of receptors for glial cell line-derived neurotrophic factor (GDNF) and neurturin in the inner blood-retinal barrier of rats. Cell Struct Funct 2000;25:237-241.

206 Eichler W, Yafai Y, Wiedemann P, Reichenbach A: Angiogenesis-related factors derived from retinal glial (Müller) cells in hypoxia. Neuroreport 2004;15:1633-1637.

207 Eichler W, Yafai Y, Keller T, Wiedemann P, Reichenbach A: PEDF derived from glial Müller cells: a possible regulator of retinal angiogenesis. Exp Cell Res 2004;299:68-78.

208 Nishikiori N, Osanai M, Chiba H, Kojima T, Mitamura Y, Ohguro H, Sawada N: Glial cell-derived cytokines attenuate the breakdown of vascular integrity in diabetic retinopathy. Diabetes 2007;56:1333-1340. 
-209 Yafai Y, Lange J, Wiedemann P, Reichenbach A, Eichler W: Pigment epithelium-derived factor acts as an opponent of growthstimulatory factors in retinal glial-endothelial cell interactions. Glia 2007;55: 642-651.

210 Keck PJ, Hauser SD, Krivi G, Sanzo K, Warren T, Feder J, Connolly DT: Vascular permeability factor, an endothelial cell mitogen related to PDGF. Science 1989;246: 1309-1312.

-211 Murata T, Nakagawa K, Khalil A, Ishibashi $\mathrm{T}$, Inomata $\mathrm{H}$, Sueishi K: The relation between expression of vascular endothelial growth factor and breakdown of the bloodretinal barrier in diabetic rat retinas. Lab Invest 1996;74:819-825.

-212 Luna JD, Chan CC, Derevjanik NL, Mahlow J, Chiu C, Peng B, Tobe T, Campochiaro PA, Vinores SA: Blood-retinal barrier (BRB) breakdown in experimental autoimmune uveoretinitis: comparison with vascular endothelial growth factor, tumor necrosis factor- $\alpha$, and interleukin-1 $\beta$-mediated breakdown. J Neurosci Res 1997;49: 268-280.

213 Aiello LP, Bursell SE, Clermont A, Duh E, Ishii H, Takagi C, Mori F, Ciulla TA, Ways K, Jirousek M, Smith LE, King GL: Vascular endothelial growth factor-induced retinal permeability is mediated by protein kinase $C$ in vivo and suppressed by an orally effective $\beta$-isoform-selective inhibitor. Diabetes 1997;46:1473-1480.

-214 Claudio L, Martiney JA, Brosnan CF: Ultrastructural studies of the blood-retina barrier after exposure to interleukin- $1 \beta$ or tumor necrosis factor- $\alpha$. Lab Invest 1994;70: 850-861.

-215 Derevjanik NL, Vinores SA, Xiao WH, Mori K, Turon T, Hudish T, Dong S, Campochiaro PA: Quantitative assessment of the integrity of the blood-retinal barrier in mice. Invest Ophthalmol Vis Sci 2002;43: 2462-2467.

216 Aiello LP, Northrup JM, Keyt BA, Takagi $\mathrm{H}$, Iwamoto MA: Hypoxic regulation of vascular endothelial growth factor in retinal cells. Arch Ophthalmol 1995;113:15381544.

217 Drescher KM, Whittum-Hudson JA: Modulation of immune-associated surface markers and cytokine production by murine retinal glial cells. J Neuroimmunol 1996;64:71-81.

-218 Amin RH, Frank RN, Kennedy A, Eliott D, Puklin JE, Abrams GW: Vascular endothelial growth factor is present in glial cells of the retina and optic nerve of human subjects with nonproliferative diabetic retinopathy. Invest Ophthalmol Vis Sci 1997; 38:36-47.

219 Eichler W, Kuhrt H, Hoffmann S, Wiedemann P, Reichenbach A: VEGF release by retinal glia depends on both oxygen and glucose supply. Neuroreport 2000;11:35333537.
220 Yafai Y, Iandiev I, Wiedemann P, Reichenbach A, Eichler W: Retinal endothelial angiogenic activity: effects of hypoxia and glial (Müller) cells. Microcirculation 2004;11: 577-586.

221 Noda K, Ishida S, Shinoda H, Koto T, Aoki T, Tsubota K, Oguchi Y, Okada Y, Ikeda E: Hypoxia induces the expression of membrane-type 1 matrix metalloproteinase in retinal glial cells. Invest Ophthalmol Vis Sci 2005;46:3817-3824.

222 Behzadian MA, Wang XL, Windsor LJ, Ghaly N, Caldwell RB: TGF- $\beta$ increases retinal endothelial cell permeability by increasing MMP-9: possible role of glial cells in endothelial barrier function. Invest Ophthalmol Vis Sci 2001;42:853-859.

223 Giebel SJ, Menicucci G, McGuire PG, Das A: Matrix metalloproteinases in early diabetic retinopathy and their role in alteration of the blood-retinal barrier. Lab Invest 2005;85:597-607.

224 Reichenbach A, Wurm A, Pannicke T, Iandiev I, Wiedemann P, Bringmann A: Müller cells as players in retinal degeneration and edema. Graefes Arch Clin Exp Ophthalmol 2007;245:627-636.

225 Li J, Patil RV, Verkman AS: Mildly abnormal retinal function in transgenic mice without Müller cell aquaporin-4 water channels. Invest Ophthalmol Vis Sci 2002; 43:573-579.

226 Strauss O: The retinal pigment epithelium in visual function. Physiol Rev 2005;85: 845-881.

227 Nagelhus EA, Veruki ML, Torp R, Haug FM, Laake JH, Nielsen S, Agre P, Ottersen OP: Aquaporin-4 water channel protein in the rat retina and optic nerve: polarized expression in Müller cells and fibrous astrocytes. J Neurosci 1998;18:2506-2519.

228 Iandiev I, Pannicke T, Biedermann B, Wiedemann P, Reichenbach A, Bringmann A: Ischemia-reperfusion alters the immunolocalization of glial aquaporins in rat retina. Neurosci Lett 2006;408:108-112.

229 Iandiev I, Pannicke T, Reichenbach A, Wiedemann P, Bringmann A: Diabetes alters the localization of glial aquaporins in rat retina. Neurosci Lett 2007;421:132-136.

230 Uckermann O, Kutzera F, Wolf A, Pannicke T, Reichenbach A, Wiedemann P, Wolf S, Bringmann A: The glucocorticoid triamcinolone acetonide inhibits osmotic swelling of retinal glial cells via stimulation of endogenous adenosine signaling. J Pharmacol Exp Ther 2005;315:1036-1045.

231 Weuste M, Wurm A, Iandiev I, Wiedemann P, Reichenbach A, Bringmann A: HB-EGF: increase in the ischemic rat retina and inhibition of osmotic glial cell swelling. Biochem Biophys Res Commun 2006;347:310318 .
232 Kalisch F, Wurm A, Iandiev I, Uckermann O, Dilsiz N, Reichenbach A, Wiedemann P, Bringmann A: Atrial natriuretic peptide inhibits osmotical glial cell swelling in the ischemic rat retina: dependence on glutamatergic-purinergic signaling. Exp Eye Res 2006;83:962-971.

233 Hirrlinger PG, Wurm A, Hirrlinger J, Bringmann A, Reichenbach A: Osmotic swelling characteristics of glial cells in the murine hippocampus, cerebellum and retina in situ. J Neurochem 2008;105:14051417.

234 Kuhrt H, Wurm A, Karl A, Iandiev I, Wiedemann P, Reichenbach A, Bringmann A, Pannicke T: Müller cell gliosis in retinal organ culture mimics gliotic alterations after ischemia in vivo. Int J Dev Neurosci 2008; 26:745-751.

235 Neumann F, Wurm A, Linnertz R, Pannicke T, Iandiev I, Wiedemann P, Reichenbach A, Bringmann A: Sex steroids inhibit osmotic swelling of retinal glial cells. Neurochem Res 2010;5:522-530.

236 Krügel K, Wurm A, Pannicke P, Hollborn M, Karl A, Wiedemann P, Reichenbach A, Kohen L, Bringmann A: Involvement of oxidative stress and mitochondrial dysfunction in the osmotic swelling of retinal glial cells from diabetic rats. Exp Eye Res 2011; 92:87-93.

237 Karl A, Wurm A, Pannicke T, Krügel K, Obara-Michlewska M, Wiedemann P, Reichenbach A, Albrecht J, Bringmann A: Synergistic action of hypoosmolarity and glutamine in inducing acute swelling of retinal glial (Müller) cells. Glia 2011;59:256266.

238 Iandiev I, Pannicke T, Hollborn M, Wiedemann P, Reichenbach A, Grimm C, Remé CE, Bringmann A: Localization of glial aquaporin-4 and Kir4.1 in the light-injured murine retina. Neurosci Lett 2008;434:317321.

239 Putting BJ, Zweypfenning RC, Vrensen GF, Oosterhuis JA, van Best JA: Blood-retinal barrier dysfunction at the pigment epithelium induced by blue light. Invest Ophthalmol Vis Sci 1992;33:3385-3393.

240 Grimm C, Wenzel A, Williams T, Rol P, Hafezi F, Remé CE: Rhodopsin-mediated blue-light damage to the rat retina: effect of photoreversal of bleaching. Invest Ophthalmol Vis Sci 2001;42:497-505.

241 Wenzel A, Grimm C, Samardzija M, Remé CE: Molecular mechanisms of light-induced photoreceptor apoptosis and neuroprotection for retinal degeneration. Prog Retin Eye Res 2005;24:275-306.

242 Yu SP, Yeh CH, Sensi SL, Gwag BJ, Canzoniero LM, Farhangrazi ZS, Ying HS, Tian M, Dugan LL, Choi DW: Mediation of neuronal apoptosis by enhancement of outward potassium current. Science 1997;278: 114-117. 
243 Bortner CD, Hughes FM Jr, Cidlowski JA: A 257 Albrecht J, Norenberg MD: Glutamine: a primary role for $\mathrm{K}^{+}$and $\mathrm{Na}^{+}$efflux in the activation of apoptosis. J Biol Chem 1997; 272:32436-32442.

-244 Szabo I, Lepple-Wienhues A, Kaba KN, Zoratti M, Gulbins E, Lang F: Tyrosine kinase-dependent activation of a chloride channel in CD95-induced apoptosis in T lymphocytes. Proc Natl Acad Sci USA 1998; 95:6169-6174

245 Maeno E, Ishizaki Y, Kanaseki T, Hazama A, Okada Y: Normotonic cell shrinkage because of disordered volume regulation is an early prerequisite to apoptosis. Proc Natl Acad Sci USA 2000;97:9487-9492.

246 Thanos S, Heiduschka P, Romann I: Exposure to a solar eclipse causes neuronal death in the retina. Graefes Arch Clin Exp Ophthalmol 2001;239:794-800.

247 Codenotti M, Patelli F, Brancato R: OCT findings in patients with retinopathy after watching a solar eclipse. Ophthalmologica 2002;216:463-466.

-248 Newman EA, Zahs KR: Calcium waves in retinal glial cells. Science 1997;275:844847.

249 Li Y, Holtzclaw LA, Russell JT: Müller cell $\mathrm{Ca}^{2+}$ waves evoked by purinergic receptor agonists in slices of rat retina. J Neurophysiol 2001;85:986-994.

-250 Wurm A, Erdmann I, Bringmann A, Reichenbach A, Pannicke T: Expression and function of $\mathrm{P} 2 \mathrm{Y}$ receptors on Müller cells of the postnatal rat retina. Glia 2009; 57:1680-1690.

-251 Bringmann A, Biedermann B, Schnurbusch U, Enzmann V, Faude F, Reichenbach A: Age- and disease-related changes of calcium channel-mediated currents in human Müller glial cells. Invest Ophthalmol Vis Sci 2000;41:2791-2796.

-252 Fine BS, Brucker AJ: Macular edema and cystoid macular edema. Am J Ophthalmol 1981;92:466-481.

-253 Yanoff M, Fine BS, Brucker AJ, Eagle RC: Pathology of human cystoid macular edema. Surv Ophthalmol 1984;28:S505-S511.

-254 Stepinac TK, Chamot SR, Rungger-Brändle E, Ferrez P, Munoz JL, van den Bergh $\mathrm{H}$, Riva CE, Pournaras CJ, Wagnieres GA: Light-induced retinal vascular damage by Pd-porphyrin luminescent oxygen probes. Invest Ophthalmol Vis Sci 2005;46:956966.

-255 Löffler S, Wurm A, Kutzera F, Pannicke T, Krügel K, Linnertz $R$, Wiedemann $P$, Reichenbach A, Bringmann A: Serum albumin induces osmotic swelling of rat retinal glial cells. Brain Res 2010;1317:268-276.

-256 Gardner TW, Antonetti DA, Barber AJ, LaNoue KF, Levison SW, The Penn State Retina Research Group: Diabetic retinopathy: more than meets the eye. Surv Ophthalmol 2002;47:S253-S262. Trojan horse in ammonia neurotoxicity. Hepatology 2006;44:788-794.

258 Reichenbach A, Kasper M, El-Hifnawi E, Eckstein AK, Fuchs U: Hepatic retinopathy: morphological features of retinal glial (Müller) cells accompanying hepatic failure. Acta Neuropathol 1995;90:273-281.

259 Reichenbach A, Stolzenburg JU, Wolburg H, Härtig W, El-Hifnawi E, Martin H: Effects of enhanced extracellular ammonia concentration on cultured mammalian retinal glial (Müller) cells. Glia 1995;13:195208.

260 Albrecht J, Gadamski R, Kuhrt H, Walski M, Reichenbach A: Retinal gliopathy accompanying thioacetamide-induced liver insufficiency: light and electron microscopic observations. Acta Neuropathol 1998;96:57-66.

261 Heuman DM, Abou-Assi SG, Habib A, Williams LM, Stravitz RT, Sanyal AJ, Fisher RA, Mihas AA: Persistent ascites and low serum sodium identify patients with cirrhosis and low MELD scores who are at high risk for early death. Hepatology 2004; 40:802-810.

262 Ruf AE, Kremers WK, Chavez LL, Descalzi VI, Podesta LG, Villamil FG: Addition of serum sodium into the MELD score predicts waiting list mortality better than MELD alone. Liver Transpl 2005;11:336343.

263 Rowan S, Cepko CL: Genetic analysis of the homeodomain transcription factor $\mathrm{Chx} 10$ in the retina using a novel multifunctional BAC transgenic mouse reporter. Dev Biol 2004;271:388-402.

264 Blackshaw S, Harpavat S, Trimarchi J, Cai L, Huang H, Kuo WP, Weber G, Lee K, Fraioli RE, Cho SH, Yung R, Asch E, OhnoMachado L, Wong WH, Cepko CL: Genomic analysis of mouse retinal development. PLoS Biol 2004;2:E247.

265 Das AV, Mallya KB, Zhao X, Ahmad F, Bhattacharya S, Thoreson WB, Hegde GV, Ahmad I: Neural stem cell properties of Müller glia in the mammalian retina: regulation by Notch and Wnt signaling. Dev Biol 2006;299:283-302.

266 Bernardos RL, Barthel LK, Meyers JR, Raymond PA: Late-stage neuronal progenitors in the retina are radial Müller glia that function as retinal stem cells. J Neurosci 2007;27:7028-7040.

267 Roesch K, Jadhav AP, Trimarchi JM, Stadler MB, Roska B, Sun BB, Cepko CL: The transcriptome of retinal Müller glial cells. J Comp Neurol 2008;509:225-238.

268 Fischer AJ, Reh TA: Müller glia are a potential source of neural regeneration in the postnatal chicken retina. Nat Neurosci 2001;4:247-252.
269 Fischer AJ, Reh TA: Potential of Müller glia to become neurogenic retinal progenitor cells. Glia 2003;43:70-76.

270 Ooto S, Akagi T, Kageyama R, Akita J, Mandai M, Honda Y, Takahashi M: Potential for neural regeneration after neurotoxic injury in the adult mammalian retina. Proc Natl Acad Sci USA 2004;101:1365413659.

271 Chang ML, Wu CH, Jiang-Shieh YF, Shieh JY, Wen CY: Reactive changes of retinal astrocytes and Müller glial cells in kainateinduced neuroexcitotoxicity. J Anat 2007; 210:54-65.

272 Wan J, Zheng H, Chen ZL, Xiao HL, Shen ZJ, Zhou GM: Preferential regeneration of photoreceptor from Müller glia after retinal degeneration in adult rat. Vision Res 2008; 48:223-234.

273 Takeda M, Takamiya A, Jiao JW, Cho KS, Trevino SG, Matsuda T, Chen DF: $\alpha$-Aminoadipate induces progenitor cell properties of Müller glia in adult mice. Invest Ophthalmol Vis Sci 2008;49:1142-1150.

274 Limb GA, Salt TE, Munro PM, Moss SE, Khaw PT: In vitro characterization of a spontaneously immortalized human Müller cell line (MIO-M1). Invest Ophthalmol Vis Sci 2002;43:864-869.

275 Kubrusly RC, da Cunha MC, Reis RA, Soares H, Ventura AL, Kurtenbach E, de Mello MC, de Mello FG: Expression of functional receptors and transmitter enzymes in cultured Müller cells. Brain Res 2005; 1038:141-149.

-276 Kubota A, Nishida K, Nakashima K, Tano Y: Conversion of mammalian Müller glial cells into a neuronal lineage by in vitro aggregate-culture. Biochem Biophys Res Commun 2006;351:514-520.

277 Lawrence JM, Singhal S, Bhatia B, Keegan DJ, Reh TA, Luthert PJ, Khaw PT, Limb GA: MOI-M1 cells and similar Müller glial cell lines derived from adult human retina exhibit neural stem cell characteristics. Stem Cells 2007;25:2033-2043.

278 Osakada F, Ooto S, Akagi T, Mandai M, Akaike A, Takahashi M: Wnt signaling promotes regeneration in the retina of adult mammals. J Neurosci 2007;27:4210-4219.

279 Wan J, Zheng H, Xiao HL, She ZJ, Zhou GM: Sonic hedgehog promotes stem-cell potential of Müller glia in the mammalian retina. Biochem Biophys Res Commun 2007;363:347-354

280 Bull ND, Limb GA, Martin K: Human Müller stem cell (MIO-M1) transplantation in a rat model of glaucoma: survival, differentiation and integration. Invest Ophthalmol Vis Sci 2008;49:3449-3456.

281 Mayer EJ, Hughes EH, Carter DA, Dick AD: Nestin positive cells in adult human retina and in epiretinal membranes. Br J Ophthalmol 2003;87:1154-1158. 